\title{
Production of scandium radionuclides for theranostic applications: towards standardization of quality requirements
}

\author{
R. Mikolajczak' , S. Huclier-Markai ${ }^{2,3^{*}}$ (D, C. Alliot ${ }^{3,4}$, F. Haddad ${ }^{2,3}$, D. Szikra ${ }^{5,6}$, V. Forgacs ${ }^{5}$ and P. Garnuszek
}

\author{
* Correspondence: sandrine. \\ huclier@subatech.in2p3.fr; huclier@ \\ arronax-nantes.fr \\ ${ }^{2}$ Laboratoire Subatech, UMR 6457, \\ IMT Nantes Atlantique /CNRS-IN2P3 \\ / Université de Nantes, 4 Rue A. \\ Kastler, BP 20722, 44307 Nantes \\ Cedex 3, France \\ ${ }^{3}$ ARRONAX GIP, 1 rue Aronnax \\ 44817 Nantes Cedex, France \\ Full list of author information is \\ available at the end of the article
}

\begin{abstract}
In the frame of "precision medicine", the scandium radionuclides have recently received considerable interest, providing personalised adjustment of radiation characteristics to optimize the efficiency of medical care or therapeutic benefit for particular groups of patients. Radionuclides of scandium, namely scandium- 43 and scandium-44 $\left({ }^{43 / 44} \mathrm{Sc}\right)$ as positron emitters and scandium- $47\left({ }^{47} \mathrm{Sc}\right)$, beta-radiation emitter, seem to fit ideally into the concept of theranostic pair. This paper aims to review the work on scandium isotopes production, coordination chemistry, radiolabeling, preclinical studies and the very first clinical studies. Finally, standardized procedures for scandium-based radiopharmaceuticals have been proposed as a basis to pave the way for elaboration of the Ph.Eur. monographs for perspective scandium radionuclides.
\end{abstract}

Keywords: Scandium radionuclides, Accelerator- and nuclear reactor production , Coordination, Radiolabeling, In vivo studies, Quality specifications

\section{Introduction}

In the quest for new radionuclides providing personalised adjustment of radiation characteristics to optimize the efficiency of medical care or therapeutic benefit for particular groups of patients (the so called "precision medicine"), the scandium radionuclides have recently received considerable interest. In the last two decades, several new radionuclides for diagnostic imaging and therapy have been successfully introduced to clinical practice. Additionally, using the same targeting vectors and the combination of positron emitter gallium-68 $\left({ }^{68} \mathrm{Ga}\right)$ for diagnostic imaging and matching therapeutic counterpart betaemitting radionuclides such as lutetium-177 $\left({ }^{177} \mathrm{Lu}\right)$ and yttrium-90 $\left({ }^{90} \mathrm{Y}\right)$ or, recently, alpha emitters bismuth-213 $\left({ }^{213} \mathrm{Bi}\right)$ and actinium-225 $\left({ }^{225} \mathrm{Ac}\right)$, for therapeutic use, has been recognized as a clear advantage over currently available treatment options. From this perspective, radionuclides of scandium, namely scandium- 43 and scandium-44 $\left({ }^{43 / 44} \mathrm{Sc}\right)$ as positron emitters and scandium- $47\left({ }^{47} \mathrm{Sc}\right)$, beta-radiation emitter, seem to fit ideally into the concept of theranostic pair (Mausner and Srivastava 1993; HuclierMarkai et al. 2018). Scandium-47 is also a low energy $\gamma$-emitter and allows SPECT and

(c) The Author(s). 2021 Open Access This article is licensed under a Creative Commons Attribution 4.0 International License, which permits use, sharing, adaptation, distribution and reproduction in any medium or format, as long as you give appropriate credit to the original author(s) and the source, provide a link to the Creative Commons licence, and indicate if changes were made. The images or other third party material in this article are included in the article's Creative Commons licence, unless indicated otherwise in a credit line to the material. If material is not included in the article's Creative Commons licence and your intended use is not permitted by statutory regulation or exceeds the permitted use, you will need to obtain permission directly from the copyright holder. To view a copy of this licence, visit http://creativecommons.org/licenses/by/4.0/. 
planar imaging. Therapeutic potential of ${ }^{47} \mathrm{Sc}$ was studied at the Brookhaven National Laboratory already in the 1990s (Mausner and Srivastava 1993; Pietrelli et al. 1992). However, the rapid growth of the scandium radionuclides applications started only after the introduction of ${ }^{68} \mathrm{Ga}$-labelled compounds for PET diagnosis in the early 2000s. Scandium44 was proposed as a potential alternative to ${ }^{68} \mathrm{Ga}$ for clinical applications in 2010 by the group of Rösch in Mainz, Germany (Roesch 2012; Pruszynski et al. 2010). Similarities in chemistry between ${ }^{68} \mathrm{Ga}$ and ${ }^{44} \mathrm{Sc}$ and their different physical properties have opened a wider avenue for applications of other Sc radionuclides.

Scandium radioisotopes can be produced in accelerators and in nuclear reactors (Huclier-Markai et al. 2018; Muller et al. 2018; Mikolajczak et al. 2019). In particular, due to their large number, biomedical cyclotrons accelerating protons up to $20 \mathrm{MeV}$ are expected to provide ${ }^{43} \mathrm{Sc}$ and ${ }^{44 \mathrm{~g}} \mathrm{Sc}$ in quantities that would allow their wider use in diagnostic imaging (Roesch 2012; Synowiecki et al. 2018). Similarly, cyclotrons accelerating protons to higher energies, nuclear reactors and electron linear accelerators (linacs) might be a source of ${ }^{47} \mathrm{Sc}$ for therapy (Domnanich et al. 2017a; Jalilian et al. 2020; Qaim 2019). However, due to several production routes possible, the unification of quality parameters of Sc radionuclides has not been yet attempted.

\section{Scandium isotopes with medical potential}

Natural scandium has only one stable isotope, scandium-45 $\left({ }^{45} \mathrm{Sc}\right)$. Several other scandium isotopes can be produced artificially, however, most of them are short-lived, in seconds range (http://kcvs.ca/isotopesmatter/iupacMaterials/javascript/Interactive\% 2 0Periodic\%20Table\%20of\%20the\%20Isotopes/HTML5/pdf-elements/scandium.pdf).

Those with atomic mass smaller than 45 decay by emission of positrons, while those with atomic mass greater than 45 emit electrons. Characteristics of Sc radioisotopes with longer half-lives are given in Table 1 (adapted from Pawlak et al. 2019). Among them, ${ }^{43} \mathrm{Sc},{ }^{44,44 \mathrm{~m}} \mathrm{Sc}$ and ${ }^{47} \mathrm{Sc}$ are suitable for medical applications.

\section{Nuclear data and production methodologies}

Production routes for ${ }^{43} \mathrm{Sc},{ }^{44 \mathrm{~g},}{ }^{44 \mathrm{~m}_{\mathrm{Sc}}}$ and ${ }^{47} \mathrm{Sc}$ use either calcium, titanium or vanadium targets, typically enriched for the desired isotope. A summary of nuclear reactions, decay data, cross-sections, and targetry is given in Table 2, together with the chemical form, purity, enrichment and cost assessment of the target material (where available). For each of the radionuclides, we also report the production mode (i.e. accelerator, nuclear reactor, radionuclide generator) and examples of production facilities that have already implemented their production.

\section{${ }^{43}$ Sc production}

$$
{ }^{43} \mathrm{Sc}\left(\mathrm{T}_{1 / 2}=3.89 \mathrm{~h}, \mathrm{E}_{\beta}{ }^{+}=476 \mathrm{keV}(88.1 \%) \text {, branching ratio } \beta^{+}: 88 \%, \mathrm{E} \gamma=372 \mathrm{keV}(22.5 \%)\right.
$$

Several production routes are possible for ${ }^{43} \mathrm{Sc}$, involving proton, deuteron or alpha beams (Chaple and Lapi 2018; Braccini 2016). These differents production routes are described in more detail below. 
Table 1 Physical characteristics of relevant Sc radioisotopes

\begin{tabular}{|c|c|c|c|}
\hline Radionuclide & Half-life & Decay mode & Energy of particles or photons (keV) \\
\hline \multirow[t]{3}{*}{${ }^{43} \mathrm{SC}$} & $3.89 \mathrm{~h}$ & $\beta^{+}$ & 1198 \\
\hline & & & 825 \\
\hline & & Y & 372 \\
\hline \multirow[t]{2}{*}{${ }^{449} \mathrm{SC}$} & $3.97 h^{a}$ & $\beta^{+}$ & 1475 \\
\hline & & Y & 1157 \\
\hline \multirow[t]{4}{*}{${ }^{44 m} \mathrm{SC}$} & $58.6 \mathrm{~h}$ & Y & 271 \\
\hline & & & 1002 \\
\hline & & & 1126 \\
\hline & & & 1157 \\
\hline \multirow[t]{3}{*}{${ }^{46} \mathrm{SC}$} & $83.79 d$ & $\beta^{-}$ & 357 \\
\hline & & Y & 889 \\
\hline & & & 1121 \\
\hline \multirow[t]{4}{*}{${ }^{47} \mathrm{SC}$} & $3.35 d$ & $\beta^{-}$ & 600 \\
\hline & & & 439 \\
\hline & & Y & 153 \\
\hline & & & 1120 \\
\hline \multirow[t]{5}{*}{${ }^{48} \mathrm{SC}$} & $43.7 \mathrm{~h}$ & $\beta^{-}$ & 654 \\
\hline & & & 485 \\
\hline & & Y & 183 \\
\hline & & & 1037 \\
\hline & & & 1312 \\
\hline
\end{tabular}

${ }^{a}$ It is worth noting that most of the sources provide the half-life of ${ }^{44} \mathrm{Sc} \mathrm{T}_{1 / 2}=3.97 \mathrm{~h}$. This value has been recently redetermined by Garcia-Tarrano et al. (Garcia-Torano et al. 2016) to be $T_{1 / 2}=4.042 \mathrm{~h}$, about $2 \%$ higher than the earlier recommended value

\section{Production of ${ }^{43} \mathrm{Sc}$ using alpha beams}

Reasonable activities of ${ }^{43} \mathrm{Sc}$ can be produced by irradiating a ${ }^{\text {nat }} \mathrm{Ca}$ target. It is obtained both directly throught ${ }^{40} \mathrm{Ca}(\alpha, \mathrm{p}){ }^{43} \mathrm{Sc}$ and ${ }^{40} \mathrm{Ca}(\alpha, \mathrm{n}){ }^{43} \mathrm{Ti} \quad\left(\mathrm{T}_{1 / 2}=509 \mathrm{~ms}\right) \rightarrow{ }^{43} \mathrm{Sc}$ nuclear reactions, using accelerators. Effective production of ${ }^{43} \mathrm{Sc}$ using alpha beam was presented by Walczak et al. (Walczak et al. 2015). Szkliniarz et al. (Szkliniarz et al. 2016) irradiated natural calcium as calcium carbonate with $20 \mathrm{MeV}$ alpha particle beam. Resulting ${ }^{43} \mathrm{Ti}$ decays to ${ }^{43} \mathrm{Sc}$ during the irradiation and no chemistry is needed to separate ${ }^{43} \mathrm{Sc}$ from ${ }^{43} \mathrm{Ti}$ due to its very short half-life. Impurities ${ }^{44 \mathrm{~m}} \mathrm{Sc}$ and ${ }^{44 \mathrm{~g}} \mathrm{Sc}$ are formed due to the ${ }^{42} \mathrm{Ca}$ content $(0.65 \%)$ in the natural calcium target as well as ${ }^{46} \mathrm{Sc}$ and ${ }^{47} \mathrm{Sc}$ due to the ${ }^{44} \mathrm{Ca}$ content ( $2 \%$ of natural calcium). The ${ }^{42} \mathrm{Ca}(\alpha, \mathrm{np}+\mathrm{pn}){ }^{46} \mathrm{Sc}$ nuclear reaction has a maximum cross-section around $30 \mathrm{MeV}$, thus its formation can be decreased by using lower beam energy. Conversely, ${ }^{47} \mathrm{Sc}$ formation cannot be avoided, as it has a similar maximum $(17 \mathrm{MeV})$ as the ${ }^{40} \mathrm{Ca}(\alpha, \mathrm{p}){ }^{43} \mathrm{Sc}$ reaction $(14 \mathrm{MeV})$. The radionuclidic purity of the produced ${ }^{43} \mathrm{Sc}$ was $99.95 \%$ at the end of bombardment (EOB) and $98.9 \%$ at $20 \mathrm{~h}$ after EOB. The radionuclidic purity decreases with time as ${ }^{43} \mathrm{Sc}$ half life is lower than that of ${ }^{44 \mathrm{~m}} \mathrm{Sc},{ }^{46} \mathrm{Sc}$ and ${ }^{47} \mathrm{Sc}$. The use of enriched ${ }^{40} \mathrm{CaCO}_{3}$ target material decreased dramatically the level of radionuclidic impurities to $1.5 \times$ $10^{-5} \%$. Thick target yield for irradiation of calcium metal was found to be $240 \mathrm{MBq} /$ $\mu \mathrm{Ah}$, from which $15 \mathrm{GBq}$ production yield was extrapolated for $4 \mathrm{~h}$ irradiation with a $25 \mu \mathrm{A}$ alpha particle beam. Based on the experimental results, $1 \mathrm{GBq}$ yield of ${ }^{44 \mathrm{~m}} \mathrm{Sc}$ is 


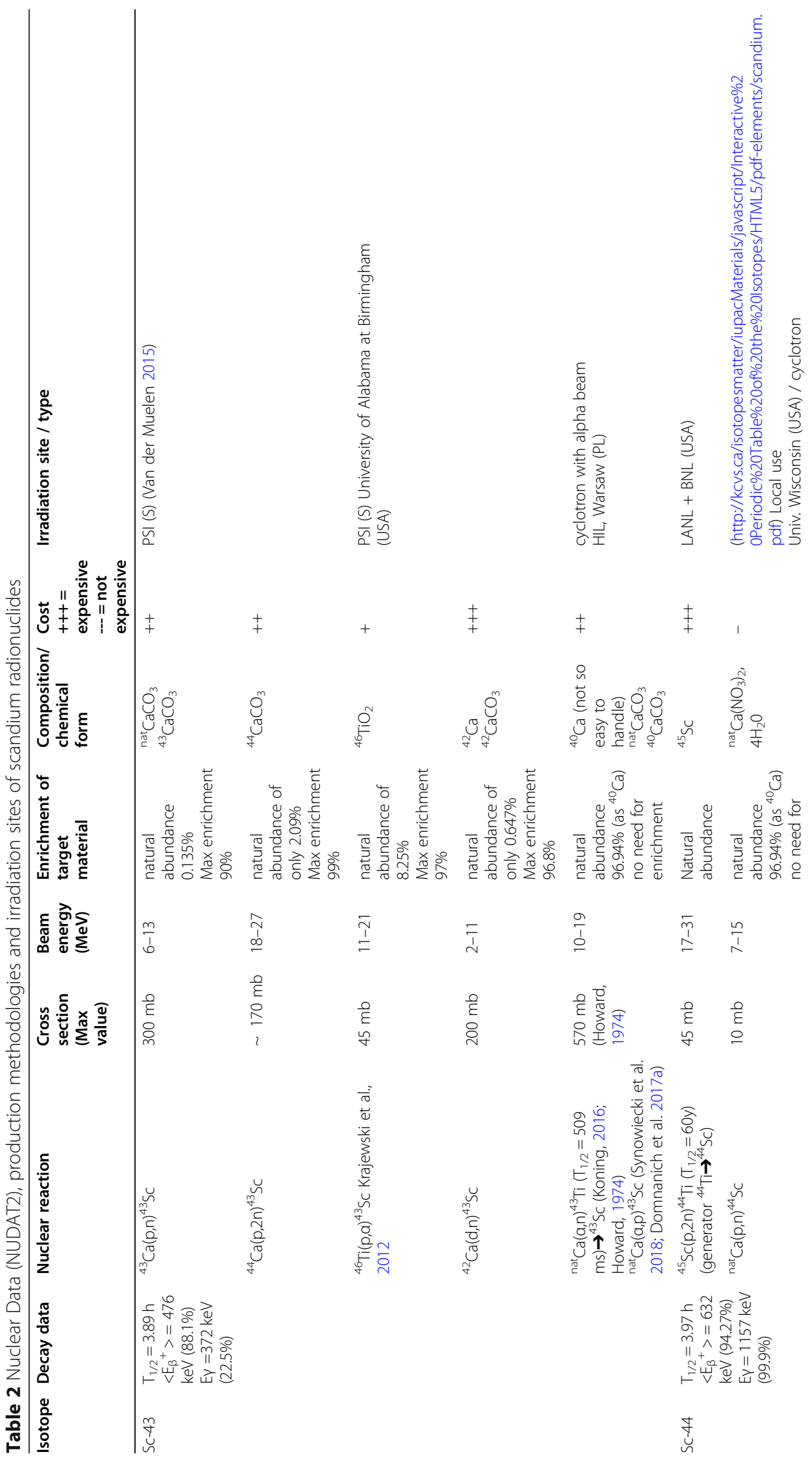




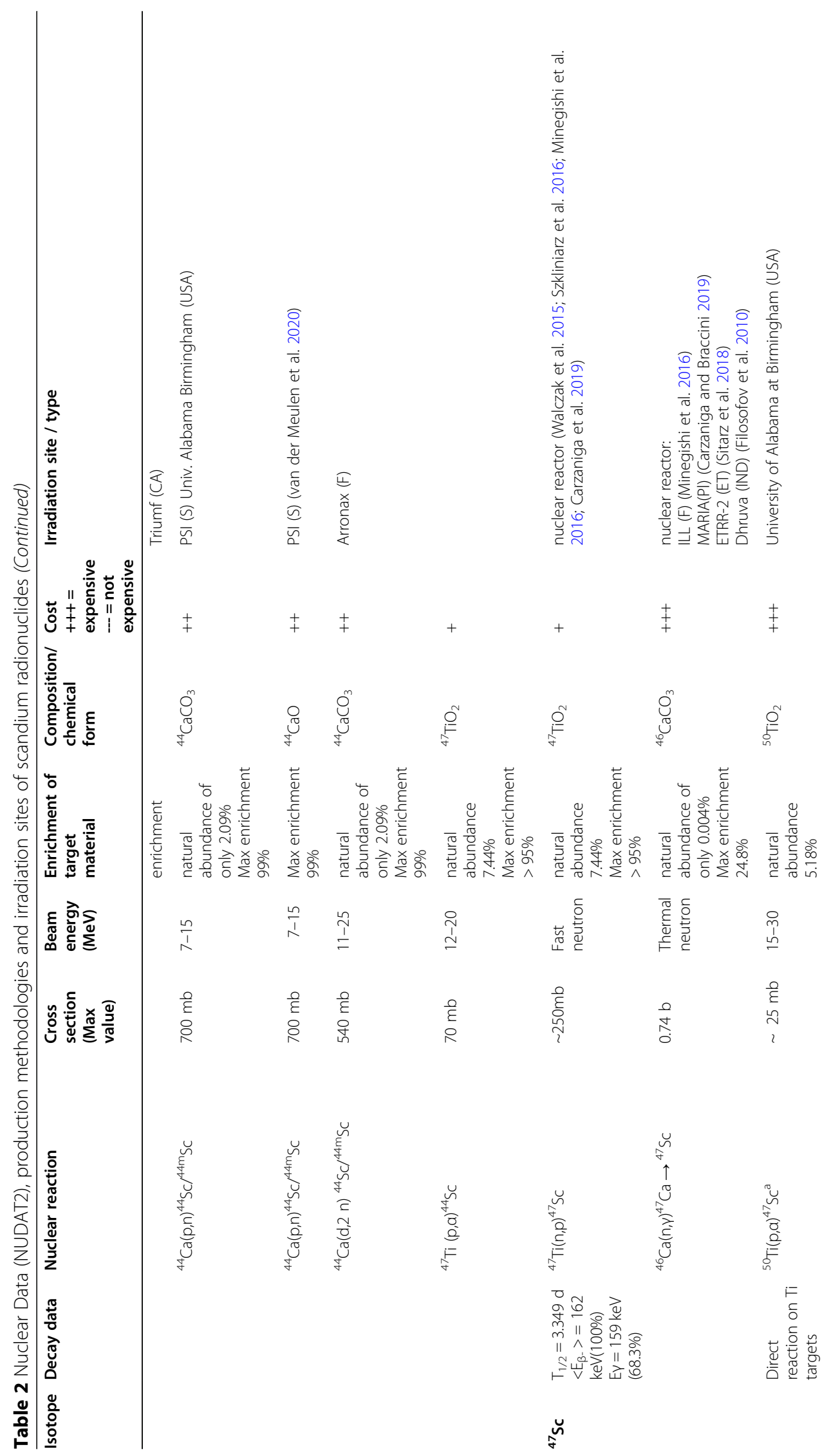




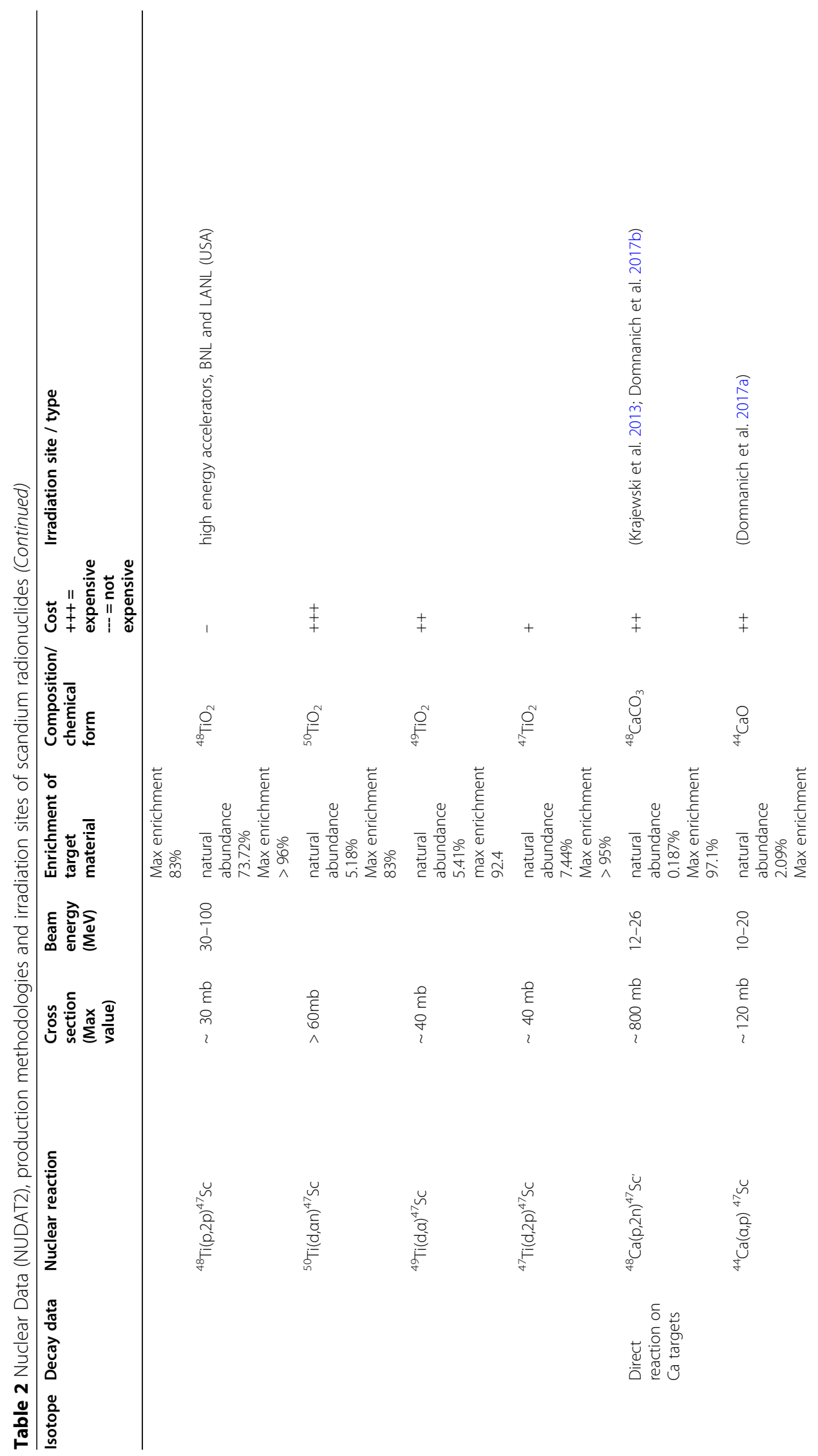




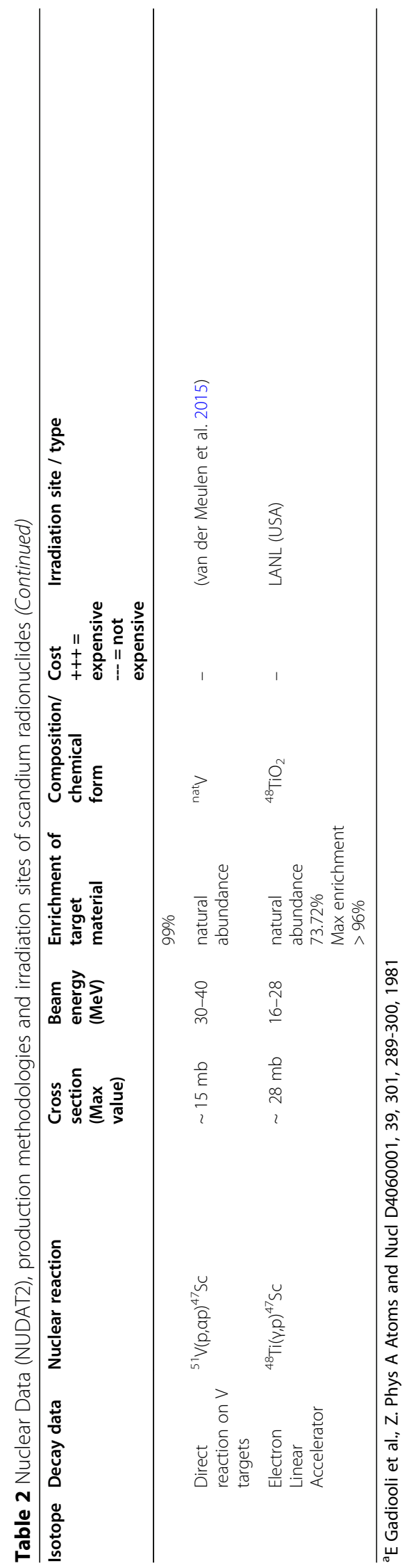


expected for high beam current alpha irradiation $(12 \mathrm{~h}, 25 \mu \mathrm{A})$ of enriched ${ }^{42} \mathrm{CaCO}_{3}$ target (Szkliniarz et al. 2016). Using alpha beam irradiation, Minegishi et al. (Minegishi et al. 2016) reported a remote method for ${ }^{43} \mathrm{Sc}$ production on an unsolidified, powder calcium oxide $(\mathrm{CaO})$ target. The powdery $\mathrm{CaO}$ target material was dissolved in situ in $\mathrm{HCl}$ in the target box and remotely recovered as a radio-Sc solution as it is done when using liquid targets. The yield of ${ }^{43} \mathrm{Sc}$ following isolation via a precipitation method with a typical $0.22 \mu \mathrm{m}$ sterile filter was $54.8 \mathrm{MBq} / \mu \mathrm{Ah}$ at the end of separation (approximately $1.5 \mathrm{~h}$ from the EOB).

\section{Production of ${ }^{43} \mathrm{SC}$ using protons}

The number of cyclotrons providing regular and intense alpha beams is limited, therefore, production methods using medical cyclotrons (proton beams) are gaining more interest. Domnanich et al. (Domnanich et al. 2017b) demonstrated that ${ }^{43} \mathrm{Sc}$ can be produced at a medical cyclotron via proton irradiation of enriched ${ }^{43} \mathrm{Ca}$ or ${ }^{46} \mathrm{Ti}$ oxide target. The production via the ${ }^{46} \mathrm{Ti}(\mathrm{p}, \alpha){ }^{43} \mathrm{Sc}$ nuclear reaction yielded a ${ }^{43} \mathrm{Sc}$ activity around $200 \mathrm{MBq}$ and high radionuclidic purity $(>98 \%)$ at the end of a $7 \mathrm{~h}$ irradiation when using $97 \%$ enriched ${ }^{46} \mathrm{Ti}$. The production via the ${ }^{43} \mathrm{Ca}(\mathrm{p}, \mathrm{n}){ }^{43} \mathrm{Sc}$ nuclear reaction resulted in higher quantities of ${ }^{43} \mathrm{Sc}$, but the product consisted of a mixture of ${ }^{43} \mathrm{Sc}$ and ${ }^{44 \mathrm{~g}} \mathrm{Sc}$ and an activity ratio of $2: 1$ when using $57.9 \%$ enriched ${ }^{43} \mathrm{CaCO}_{3}$. This may be increased with higher enrichment of the ${ }^{43} \mathrm{Ca}$ target ( $\max$ available is $90 \%$ at the moment). However, the question remains whether ${ }^{44 \mathrm{~g}} \mathrm{Sc}$ is a real problem as it decays with almost the same half-life by emitting a positron, as ${ }^{43} \mathrm{Sc}$.

\section{Production of ${ }^{43} \mathrm{Sc}$ using deuterons}

${ }^{43} \mathrm{Sc}$ can be also produced by deuteron bombardment of an enriched ${ }^{42} \mathrm{Ca}$ oxide target, although the method has not been yet practically utilized. Recently, measurements of the ${ }^{43} \mathrm{Sc}$ production cross-section in the reaction ${ }^{42} \mathrm{Ca}(\mathrm{d}, \mathrm{n}){ }^{43} \mathrm{Sc}$ with a deuteron beam have been reported by Carzaniga et al. (Carzaniga et al. 2019; Carzaniga and Braccini 2019). The authors also studied practical aspects of producing ${ }^{43} \mathrm{Sc}$ via this route using commercially available targets. Yet, the limited number of medical cyclotrons currently in operation offering deuteron beams prevents the wider application of this method.

In summary, ${ }^{43} \mathrm{Sc}$ can be produced with proton and deuteron beams that are easily available worldwide, the use of enriched (and expensive) target material, ${ }^{43} \mathrm{Ca}$ or ${ }^{44} \mathrm{Ca}$, is mandatory due to their low natural abundance. When proton irradiation route is preferred, the issue of co-produced ${ }^{44 \mathrm{~g}} \mathrm{Sc}$ in ${ }^{43} \mathrm{Sc}$ needs to be addressed (Sitarz et al. 2018). On the other hand, irradiation with an alpha particle beam allows to use directly natural calcium as the nuclear reaction of interest involves ${ }^{40} \mathrm{Ca}$ (natural abundance is 96.94\%). However, such a kind of beam is only available in a few places in the world. Though, higher radionuclidic purity can be obtained using enriched ${ }^{40} \mathrm{Ca}$ target, that is more affordable than other enriched calcium materials.

\section{${ }^{449} \mathrm{Sc}$ production}

$$
{ }^{44 g} \mathrm{Sc}\left(\mathrm{T}_{1 / 2}=3.97 \mathrm{~h}, \mathrm{E}_{\beta}{ }^{+}=632 \mathrm{keV}(94.27 \%) \text {, branching ratio } \beta^{+}: 94.3 \%, \mathrm{E}_{\gamma}=1157 \mathrm{keV}(99.9 \%)\right)
$$

${ }^{44 \mathrm{~g}} \mathrm{Sc}$ can be obtained directly by irradiation of an enriched ${ }^{44} \mathrm{Ca}$ target of different chemical forms or via the use of the ${ }^{44} \mathrm{Ti} /{ }^{44 \mathrm{~g}} \mathrm{Sc}$ generator. The main difference of the 
two methods is that in the first case, there is a co-production of ${ }^{44 \mathrm{~m}} \mathrm{Sc}\left(\mathrm{T}_{1 / 2}=58.61 \mathrm{~h}\right)$ which is not present in the generator produced ${ }^{44} \mathrm{Sc}$.

\section{${ }^{44} \mathrm{Ti}{ }^{44 g} \mathrm{SC}$ generators}

${ }^{44} \mathrm{Ti} /{ }^{44 \mathrm{~g}} \mathrm{Sc}$ generator has been proposed as a source of ${ }^{44 \mathrm{~g}} \mathrm{Sc}$ (Roesch 2012; Filosofov et al. 2010; Radchenko et al. 2016). Although the generator method has been extensively investigated, only a small number of facilities worldwide use these generators. The parent radionuclide, titanium-44 $\left(\mathrm{T}_{1 / 2}=60 \mathrm{y}\right)$ is produced through the nuclear reaction ${ }^{45} \mathrm{Sc}(\mathrm{p}, 2 \mathrm{n}){ }^{44} \mathrm{Ti}$. Production of $\mathrm{mCi}$ amount of ${ }^{44} \mathrm{Ti}$ is difficult due to its long half-life and the low cross section (probability) of this nuclear reaction. As an example, irradiation of $1.5 \mathrm{~g}$ of $\mathrm{Sc}$ target material produced about $185 \mathrm{MBq}(5 \mathrm{mCi})$ (Chaple and Lapi 2018).

\section{Production of ${ }^{44} \mathrm{Sc}$ using protons}

It is thus easier to use an accelerator to produce ${ }^{44 \mathrm{~g}} \mathrm{Sc}$. Medical cyclotron can be used for proton irradiation of a target containing either natural (Severin et al. 2012) or ${ }^{44} \mathrm{Ca}$ enriched target (Krajewski et al. 2013). Enriched targets are preferred to avoid the production of contaminants such as ${ }^{46,48} \mathrm{Sc}$ (Domnanich et al. 2017a). The higher the ${ }^{44} \mathrm{Ca}$ enrichment, the higher the final radionuclidic purity. However, during the irradiation, ${ }^{44 \mathrm{~m}} \mathrm{Sc}$ is co-produced which may be either an advantage or a disadvantage depending on the application. Indeed, its long half life allows ${ }^{44 \mathrm{~m}} \mathrm{Sc}\left(\mathrm{T}_{1 / 2}=58.6 \mathrm{~h}\right)$ to be used to image slow biological processes. This is possible since ${ }^{44 \mathrm{~m}} \mathrm{Sc} /{ }^{44 \mathrm{~g}} \mathrm{Sc}$ can act as an in-vivo generator (Alliot et al., 2015a). The production of ${ }^{44 \mathrm{~g}} \mathrm{Sc}$ via the ${ }^{44} \mathrm{Ca}(\mathrm{p}, \mathrm{n}){ }^{44 \mathrm{~g}} \mathrm{Sc}$ nuclear reaction has been implemented at the research cyclotron at Paul Scherrer Institute, Zurich, providing this radionuclide with high radionuclidic purity $(>99 \%)$ and at high activities (>2 GBq) (van der Meulen et al. 2015). This would be the method of choice when one wants to produce cost effectively ${ }^{44 \mathrm{~S}} \mathrm{Sc}$. Other targets or projectiles have also been used, presenting some advantages for dedicated cases: higher contribution of ${ }^{44 \mathrm{~m}} \mathrm{Sc}$ for example or lower cost when using ${ }^{\text {nat }} \mathrm{Ca}$. The use of natural calcium metal provides cost-efficient access to ${ }^{44 g} \mathrm{Sc}$ for preclinical experiments. It can be pressed into the cavity of an appropriate target holder (coin or shuttle) and irradiated with high currents, as it has good heat conductivity. However, contaminating radiometals prevent the use of this production route for human application. Exotic production routes have been also studied using ${ }^{47} \mathrm{Ti}$ in a ${ }^{47} \mathrm{Ti}(\mathrm{p}, \alpha){ }^{44} \mathrm{Sc}$ nuclear reaction (Loveless et al. 2021).

\section{Production of ${ }^{44} \mathrm{Sc}$ using deuterons}

Deuteron beams can also be used for production of ${ }^{44} \mathrm{Sc}$ in a nuclear reaction ${ }^{44} \mathrm{Ca}(\mathrm{d}$, 2n) ${ }^{44} \mathrm{Sc} /{ }^{44 \mathrm{~m}} \mathrm{Sc}$ (Alliot et al. 2015a). A proof of principle has been demonstrated at low beam current $(0.3 \mu \mathrm{A})$. An activity of $90 \mathrm{MBq}(4 \mathrm{~h}$ after EOB) can be obtained with a 3 h bombardment on a $500 \mu \mathrm{m}$ thick ${ }^{44} \mathrm{CaCO}_{3}$ target at $17 \mathrm{MeV}$ (Alliot et al. 2015b). This study showed also that the use of deuterons allows to increase the production of ${ }^{44 \mathrm{~m}} \mathrm{Sc}$ with respect to proton irradiation keeping ${ }^{44 \mathrm{~g}} \mathrm{Sc}$ at the same level as for protons (Duchemin et al. 2015; Duchemin et al. 2016). However, to favor ${ }^{44 \mathrm{~m}} \mathrm{Sc}$ production the use of alpha beam is recommended (Szkliniarz et al. 2016). 
${ }^{47}$ Sc production

$$
{ }^{47} \mathrm{Sc}\left(\mathrm{T}_{1 / 2}=3.349 \mathrm{~d}, \mathrm{E}_{\beta-}=162 \mathrm{keV}(100 \%), \mathrm{E}_{\gamma}=159 \mathrm{keV}(68.3 \%)\right)
$$

Scandium-47 can be produced via several different nuclear reactions using a nuclear reactor, a cyclotron, or a linac (Srivastava 2013).

\section{Production of ${ }^{47}$ Sc using neutrons}

In a nuclear reactor, practically n.c.a ${ }^{47} \mathrm{Sc}$ is produced via ${ }^{47} \mathrm{Ti}(\mathrm{n}, \mathrm{p}){ }^{47} \mathrm{Sc}$ nuclear reaction by irradiation of ${ }^{47} \mathrm{Ti}$ target with fast neutrons (energy greater than $\left.1 \mathrm{MeV}\right)$. The ${ }^{47} \mathrm{Ti}(\mathrm{n}$, p) ${ }^{47} \mathrm{Sc}$ route also requires an enriched target, though ${ }^{47} \mathrm{Ti}$ oxide is available with very high enrichment and at a reasonable cost. Thus, using the ${ }^{47} \mathrm{Ti}(\mathrm{n}, \mathrm{p}){ }^{47} \mathrm{Sc}$ nuclear reaction could provide quantities sufficient for therapy. For example, in a HFIR reactor (Oak Ridge National Laboratory) a 3.35 day (one half-life of ${ }^{47} \mathrm{Sc}$ ) irradiation of $10 \mathrm{~g}$ target could produce approximately $2800 \mathrm{GBq}$ of ${ }^{47} \mathrm{Sc}$ at EOB (Kolsky et al. 1998; Mausner et al. 1993). However, along with ${ }^{47} \mathrm{Sc},{ }^{46} \mathrm{Sc}$ is co-produced (Domnanich et al. 2017a; Bokhari et al. 2009; Bartoś et al. 2012). This method suffers from the limited number of facilities delivering fast neutrons.

Alternatively, ${ }^{47}$ Sc can be produced with thermal neutrons (Mausner 1998; DeilamiNezhad et al. 2016) that are more widely available. Neutron capture on ${ }^{46} \mathrm{Ca}$ produces ${ }^{47} \mathrm{Ca}\left(\mathrm{T}_{1 / 2}=4.5 \mathrm{~d}\right)$, which decays into ${ }^{47} \mathrm{Sc}$ by $\beta{ }^{-}$emission: ${ }^{46} \mathrm{Ca}(\mathrm{n}, \gamma){ }^{47} \mathrm{Ca} \rightarrow{ }^{47} \mathrm{Sc}$, and the obtained ${ }^{47} \mathrm{Ca}$ can be further exploited as the ${ }^{47} \mathrm{Ca} /{ }^{47} \mathrm{Sc}$ generator system (Mausner 1998). This method suffers mainly from the low natural abundance of ${ }^{46} \mathrm{Ca}(0.004 \%)$. Still, ${ }^{47}$ Sc production from neutron irradiated natural $\mathrm{Ca}$ target was shown to be feasible (Gizawy et al. 2020). Nontheless, to obtain significant activity of ${ }^{47} \mathrm{Ca}$ the target enriched in ${ }^{46} \mathrm{Ca}$ must be used (presently ${ }^{46} \mathrm{Ca}$ is available with a maximum $30 \%$ enrichment) which is rather expensive (Chakravarty et al. 2017) but recycling would allow to drastically reduce the cost. For comparison, when $0,97 \mathrm{mg}$ of ${ }^{46} \mathrm{Ca}(48.5 \mathrm{mg}$ of $5 \%$ enriched $\left[{ }^{46} \mathrm{Ca}\right] \mathrm{CaCO}_{3}$ ) was irradiated in a thermal neutron flux $1.2 \times 10^{14} \mathrm{~ns}^{-1} \mathrm{~cm}^{-2}$ for 6 days, around $700 \mathrm{MBq}$ of ${ }^{47} \mathrm{Ca}$ and $350 \mathrm{MBq}$ of ${ }^{47} \mathrm{Sc}$ were produced at EOB (Pawlak et al. 2019). The produced ${ }^{47} \mathrm{Ca}$ decays to ${ }^{47} \mathrm{Sc}$ with a half-life of 4.5 days, which is longer than the half-life of ${ }^{47} \mathrm{Sc}$, enabling multiple separations of in-grown ${ }^{47} \mathrm{Sc}$ in the generator-like system. Using this approach, Domnanich et al. (Domnanich et al. 2017a) demonstrated that up to $2 \mathrm{GBq}{ }^{47} \mathrm{Sc}$ can be produced by thermal neutron irradiation of enriched ${ }^{46} \mathrm{Ca}$ targets. The optimized chemical isolation of ${ }^{47} \mathrm{Sc}$ from the target material allowed the formulation of up to $1.5 \mathrm{GBq}{ }^{47} \mathrm{Sc}$ with high radionuclidic purity (> 99.99\%) in a small volume $(\sim 700 \mu \mathrm{L})$, which was useful for labeling purposes. Three consecutive separations within 1 week were possible by isolating the in-grown ${ }^{47} \mathrm{Sc}$ (Domnanich et al. 2017a; Pawlak et al. 2019).

\section{Production of ${ }^{47}$ Sc using protons}

Scandium-47 can also be produced using high energy proton reaction on ${ }^{48} \mathrm{Ti}$ (Srivastava 2013; Srivastava and Dadachova 2001). The nuclear reaction on ${ }^{48} \mathrm{Ti}$ was quite popular as the natural abundance is quite high (73.72\%) and the low cross section of the ${ }^{48} \mathrm{Ti}(\mathrm{p}, 2 \mathrm{p}){ }^{47} \mathrm{Sc}$ nuclear reaction can be partly compensated by the use of thick targets. However, this method suffers from the co-production of ${ }^{46} \mathrm{Sc}\left(\mathrm{T}_{1 / 2}=83.79 \mathrm{~d}\right)$ which emits high energy gamma rays abundantly. This impurity is a major concern in 
the production of ${ }^{47} \mathrm{Sc}$ both for the risk of unnecessary radiation dose and the regulatory constraints when stored at the therapy wards (Jafari et al. 2019).

Alternative production routes have been explored to try to overcome this issue using ${ }^{48} \mathrm{Ca},{ }^{n a t} \mathrm{~V},{ }^{44} \mathrm{Ca}$ targets or photonuclear reactions (Mausner and Srivastava 1993; Szkliniarz et al. 2016; Sitarz et al. 2018; Srivastava and Dadachova 2001). The cyclotron production of ${ }^{47} \mathrm{Sc}$ via the ${ }^{48} \mathrm{Ca}(\mathrm{p}, 2 \mathrm{n}){ }^{47} \mathrm{Sc}$ nuclear reaction with a proton energy range of $24 \rightarrow 17$ led to a radionuclidic purity of only around $87 \%$, due to ${ }^{48} \mathrm{Sc}$ co-production (Misiak et al. 2017). Using enriched ${ }^{48} \mathrm{Ca}$ for irradiation with $20 \mathrm{MeV}$ protons may be a feasible route for the production of GBq activity levels of ${ }^{47} \mathrm{Sc}$, however, the prohibitively high cost of enriched ${ }^{48} \mathrm{Ca}$ has made it impossible to implement this production route to date (Misiak et al. 2017). Still, the production of ${ }^{47} \mathrm{Sc}$ in medical cyclotrons providing proton beams at energy range of $15-20 \mathrm{MeV}$ via the ${ }^{48} \mathrm{Ca}(\mathrm{p}, 2 \mathrm{n}){ }^{47} \mathrm{Sc}$ nuclear reaction on ${ }^{48} \mathrm{Ca}$ enriched calcium oxide target could potentially provide wide access to this radionuclide (Braccini 2016). However, the co-produced ${ }^{48} \mathrm{Sc}$ undermines the ${ }^{47} \mathrm{Sc}$ purity, and its content strongly depends on the energy of protons impinging the target and on the thickness of the target material, feasibility of this approach has been studied in detail (Carzaniga and Braccini 2019). Another production route proposes the use of natural vanadium targets, since natural vanadium consists of two isotopes: for more than $99.75 \%$ it is formed by stable ${ }^{51} \mathrm{~V}$ while the very long-lived ${ }^{50} \mathrm{~V}\left(T_{1 / 2}=1.4 \times 10^{17}\right.$ y) occurs only in $0.25 \%$. Experimental data on ${ }^{\text {nat }} \mathrm{V}$ can hence be interpreted in broad energy range as coming from a monoisotopic ${ }^{51} \mathrm{~V}$ target and reaction cross-sections can be derived. The cross-sections of the ${ }^{n a t} \mathrm{~V}(\mathrm{p}, \mathrm{x})^{47} \mathrm{Sc}$ nuclear reaction were measured up to $70 \mathrm{MeV}$ proton beam (Jafari et al. 2019; Pupillo et al. 2019; Ditroi et al. 2016), the low reaction yields are the disadvantage of this approach.

\section{Production of ${ }^{47} \mathrm{Sc}$ using alpha beams}

The $\alpha$-particle irradiation of ${ }^{44} \mathrm{Ca}$ targets at a cyclotron, inducing the ${ }^{44} \mathrm{Ca}(\alpha, \mathrm{p}){ }^{47} \mathrm{Sc}$ nuclear reaction has been considered, though with low yield and radionuclidic purity. The advantage of the ${ }^{44} \mathrm{Ca}(\alpha, \mathrm{p})^{47} \mathrm{Sc}$ reaction lies in the short range of $\alpha$ projectiles in Ca target, allowing the use of a relatively small amount of ${ }^{44} \mathrm{Ca}$ target material for small scale studies with ${ }^{47} \mathrm{Sc}$. For example, it is reported that $200 \mathrm{mg}$ of $\left[{ }^{44} \mathrm{Ca}\right] \mathrm{CaO}$ prepared in a diameter of $10 \mathrm{~mm}$ would give a yield of approximately $11 \mathrm{MBq}$ at $10 \mathrm{e} \mu \mathrm{A}$ for $2 \mathrm{~h}$ irradiation at the end of preparation (approximately $1.5 \mathrm{~h}$ from the EOB) in the energy range of $28 \rightarrow 0 \mathrm{MeV}$ (Minegishi et al. 2016).

\section{Production of ${ }^{47} \mathrm{Sc}$ in photonuclear reactions}

Photonuclear reactions in electron linear accelerators (linacs) using titanium (Jafari et al. 2019; Yagi and Kondo 1977; Mamtimin et al. 2015; Rotsch et al. 2018) and calcium targets (Starovoitova et al. 2015; Rane et al. 2015) have been explored. However, the cross sections are very small. It may be more convenient to use neutrons and ${ }^{46} \mathrm{Ca}$. Mamtimin et al. (Mamtimin et al. 2015) studied the production of ${ }^{47} \mathrm{Sc}$ via the ${ }^{48} \mathrm{Ti}(\gamma, \mathrm{p}){ }^{47} \mathrm{Sc}$ nuclear reaction by Monte Carlo simulations. Rotsch et al. (Rotsch et al. 2018) evaluated the production yields and purification of the photonuclear-produced ${ }^{47} \mathrm{Sc}$ from natural titanium oxide targets. In the recent report on photonuclear production Loveless et al. (Loveless et al. 2019a) used eLINAC to produce ${ }^{47} \mathrm{Sc}$ via ${ }^{48} \mathrm{Ti}(\gamma$, 
p ${ }^{47}$ Sc reaction. They irradiated a stack of natural titanium foils using bremsstrahlung radiation generated by impinging $22 \mathrm{MeV}$ electrons onto a $0.762 \mathrm{~mm}$ thick tungsten radiator. Despite the long irradiation times (10.5-14 h) low activity (approx. $2 \mathrm{MBq}$ ) was produced with $90 \%{ }^{47} \mathrm{Sc}, 1.2 \%{ }^{46} \mathrm{Sc}$ and $8.3 \%{ }^{48} \mathrm{Sc}$ at EOB. The authors suggested the use of enriched titanium, available in oxide form for low cost. It is expected to improve the attainable radionuclidic purity, but not significantly increase the yield, as the natural abundance of ${ }^{48} \mathrm{Ti}$ is $73.7 \%$. Importantly, the use of oxide target material requires a special target design, to effectively dissipate the heat during irradiation. Accelerator-based photoproduction of ${ }^{47} \mathrm{Sc}$ in ${ }^{48} \mathrm{Ca}(\gamma, \mathrm{n}){ }^{47} \mathrm{Ca} \rightarrow{ }^{47} \mathrm{Sc}$ nuclear reaction was also reported by Starovoitova et al. (Starovoitova et al. 2015) and Rane et al. (Rane et al. 2015), the latter aiming to develop the ${ }^{47} \mathrm{Ca} /{ }^{47} \mathrm{Sc}$ generator obtained from irradiated ${ }^{48} \mathrm{Ca}$ target.

To date there is no preferred ${ }^{47} \mathrm{Sc}$ production route. The presence of radionuclide contaminants is expected in all cases. The choice depends on the availability of the irradiation sites and enriched target materials. For example, higher ${ }^{46} \mathrm{Ca}$ enrichment may favour its neutron irradiation. At the sites operating linear electron accelerators the photonulear reactions will be preferred (Qaim 2019).

\section{Targetry}

Calcium enriched in ${ }^{44} \mathrm{Ca}$, required to reach high radionuclidic purity of ${ }^{44} \mathrm{Sc}$, is available only in salt form (oxide, carbonate). The low heat conductivity of the target limits the beam current during irradiation. At high beam currents, the heat accumulation caused burnout and/or cracking of the irradiated target and may lead to gas production through the thermal dissociation of $\mathrm{CaCO}_{3}$ (Wojdowska 2019). In some application, the issue of low thermal conductivity was handled by pressing the calcium carbonate on top of graphite powder to facilitate heat transfer and to hold the calcium carbonate powder in position (van der Meulen et al. 2015). The improvment of the heat conducitivity is paid by a lower production as part of the projectile will interact with carbon atoms. However, this method yielded up to $2 \mathrm{GBq}$ of ${ }^{44} \mathrm{Sc}$ when using proton beam energies of near $11 \mathrm{MeV}$, but can not be automatized easily (see Table 2). Calcium oxide obtianed through thermal decomposition of calcium carbonate, both natural and enriched in ${ }^{44} \mathrm{Ca}$, was used for preparation of disk shaped pellets which were encapsulated into aluminum for irradiation. Thus increased density of calcium oxide improved the irradiation yield compared to carbonate, though due to the higroscopicity of $\mathrm{CaO}$ to the pellets needed to be protected from moisture during storage and when exposed to irradiation (van der Meulen et al. 2020).

Alternatively, magnesium or aluminium powder were used as an additive for target pellet preparation (Mikolajczak et al. 2018; Stolarz et al. 2018). Nuclear reactions on these atoms under $16 \mathrm{MeV}$ proton energy lead to short lived isotopes mainly, resulting in relatively little radioactive contaminants at the end of irradiation. The magnesium pellet can be selectively dissolved from an aluminium target holder with $3 \mathrm{M}$ hydrochloric acid. Aluminum is also easily dissolved after removal from the holder coin.

Introduction of the powdery target material (calcium oxide or calcium carbonate) directly into the cyclotron represents a high risk of contamination as the material may evaporate during irradiation. If a metal foil is used as a target material cover to prevent evaporation, the choice of metal needs careful consideration as it will also act as a 
degrader. When the foil is too thin, it may separate from the target material during irradiation and may burn out at higher beam currents, as it was reported at $27 \mu \mathrm{A} 16$ $\mathrm{MeV}$ on a $12.5 \mu \mathrm{m}$ aluminum foil by Severin et al. (Severin et al. 2012). Conversely, if a higher degrader thickness is required to adjust optimal energy on the target, it has to be actively cooled (van der Meulen et al. 2015). In medical cyclotrons it is safer to use helium-cooled HAVAR foils to separate the irradiated target material from the vacuum system of the cyclotron (e.g., the ARTMS system). In the target system developed in Debrecen (Mikolajczak et al. 2018), the original parts from a water target were used as an interface to the beam port of the cyclotron (see Fig. 1). This enabled the circulation of helium cooling gas between the two foils. After several months of regular use, the contamination caused by calcium evaporation was clearly visible on the internal surfaces of the target system on the second foil. However, no carbonate migrated through the foils to the cooling cycle, or to the high vacuum side.

The high investment costs and the complicated installation are usually mentioned as major drawbacks of a solid target system. Due to the more complex operation, solid target handling systems will be always more expensive than a simple liquid target but will produce 10 times more radioactivity. Installation of a shuttle type solid target system (commercially available from several companies) requires $4-5 \mathrm{~cm}$ diameter passage in the walls of the cyclotron bunker and the hot lab, and some free space in the floor duct between them. However, this can be simply made at one end and nearly impossible at another in already existing facilites.

The challenges related to solid target systems prompted the investigation of ${ }^{44} \mathrm{Sc}$ production in a liquid target. Hoehr et al. (Hoehr et al. 2014) irradiated approximately 1.5 $\mathrm{g} / \mathrm{mL}$ natural calcium nitrate solution with $13 \mathrm{MeV}$ proton beam in a relatively small volume liquid target. $28 \mathrm{MBq}{ }^{44} \mathrm{Sc}$ was produced with a $20 \mu \mathrm{A}$ beam current for $1 \mathrm{~h}$, which can reach a gigabecquerel level, if enriched target material is used. However, it is questionable, whether the production can be managed in a cost-efficient way given that a high amount of enriched material has to be irradiated (approx. 100 times more, than for a solid target production from ${ }^{44} \mathrm{CaCO}_{3}$ ). The use of liquid targets for radiometal production offers easier installation and lower hardware investment costs, but the presence of corrosive liquids on a cyclotron, which is producing ${ }^{18} \mathrm{~F}$ for daily FDG production is of high concern. IBA (Nirta Ga liquid) and GE (gallium target) also offer liquid targets for radiometal production, however, evidence showing their long-term use is needed. From the regulatory point of view, it might be necessary that a liquid target is

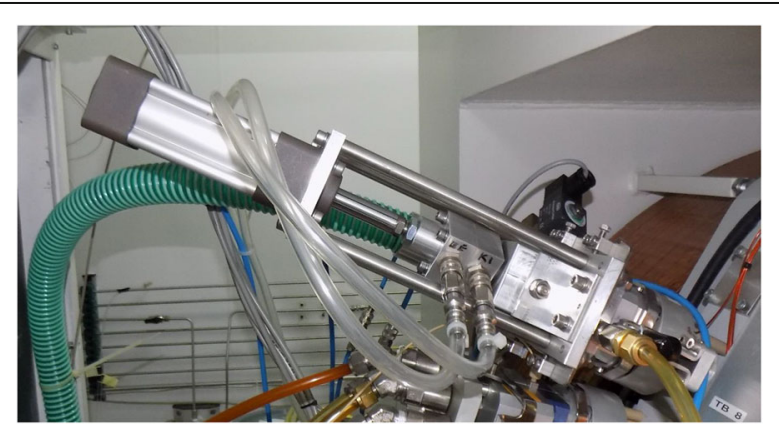

Fig. 1 Solid target system with pneumatic target transfer, developed at the University of Debrecen 
used for the production of only one radiometal. In contrast, a solid target system can be used to irradiate targets for several radiometals using dedicated target holders.

Gelbart et al. (Gelbart and Johnson 2019) developed a hybrid target system to overcome the installation problems of shuttle type systems. The equipment, used for target dissolution is located in the cyclotron bunker behind the irradiated target, allowing the transport of the produced radioisotope in solution to the hot lab. It was designed for ${ }^{99 \mathrm{~m}} \mathrm{Tc}$ and ${ }^{68} \mathrm{Ga}$ production, but can be utilized for scandium as well.

\section{Chemical processing}

Several separation methods have been described in the literature, each strongly related to the form of the initial target material. Those proposed for separation of scandium comprised mostly solvent extraction (Zhang et al. 1997; Vibhute and Khopkar 1985; Rane and Bhatki 1966; Radhakrishnan and Owens 1972; Kalyanaraman and Khopkar 2002). However, for the radioactive isotopes of scandium extraction chromatography is preferred. Cartridge- or small column-based extraction chromatography methods can be automatized easily, and enable reproducible purification. Considering the further development of scandium radionuclides production, the technical issues associated with irradiation, target handling, dissolution and processing need to be solved. For routine application in clinical trials and future diagnostic use, these steps should be automated in order to facilitate the production and to meet the requirements of GMP and radiation protection. Pourmand et al. (Pourmand and Dauphas 2010) reported the strong $\mathrm{Sc}(\mathrm{III})$ retention on DGA resin and the negligible $\mathrm{Ti}(\mathrm{III})$ retention at $\mathrm{HCl}$ molarities below $6 \mathrm{M}$. After elution with $4.0 \mathrm{~mL}$ of $\mathrm{HCl} 0.1 \mathrm{M}$ scandium is concentrated in a smaller volume by the use of second column containing SCX cation exchange resin and eluted with $4.8 \mathrm{M} \mathrm{NaCl} / 0.13 \mathrm{M} \mathrm{HCl}$ effluent. The same approach was used by van der Meulen et al. at PSI, Villigen (van der Meulen et al. 2015). A summary of different approaches developed in the literature is given in Table 3.

The purity of the resulting batches is of great importance. Most of the published works dealt with ${ }^{44} \mathrm{Sc}$. These studies have shown that a high chemical purity of the final ${ }^{44} \mathrm{Sc}$ fraction is important, since the presence of other metals may interact with the DOTA-chelator (or any other chelator) and, hence, the radiolabeling yield would be compromised. The concentration of common environmental contaminants (Al(III), $\mathrm{Cu}(\mathrm{II}), \mathrm{Pb}(\mathrm{II}), \mathrm{Zn}(\mathrm{II}), \mathrm{Fe}(\mathrm{III}))$ in ${ }^{44} \mathrm{Sc}$ is frequent. The most problematic is $\mathrm{Fe}^{3+}$ for which the stability with the DOTA ligand is greater than that for $\mathrm{Sc}^{3+}$. By contrast, the influence of divalent metal cations (considered as contaminants) is negligible due to the much lower stability of their DOTA complexes. In order to meet the requirements for radiopharmaceutical applications, the obtained final solution containing scandium radionuclide needs to be of high chemical purity and concentrated into a small volume of moderately acidic eluate to facilitate efficient radiolabeling and subsequent in vivo application. Most of the times, authors do not indicate the final chemical purity of the resulting bacthes.

\section{Target recovery}

Calcium has six naturally occurring isotopes $\left({ }^{40} \mathrm{Ca},{ }^{42} \mathrm{Ca},{ }^{43} \mathrm{Ca},{ }^{44} \mathrm{Ca},{ }^{46} \mathrm{Ca}\right.$, and $\left.{ }^{48} \mathrm{Ca}\right)$, where ${ }^{40} \mathrm{Ca}$ is the most abundant, comprising about $97 \%$ of naturally occurring calcium. 
Table 3 Separation methods related to the initial target material for getting scandium radionuclides

\section{Starting Separation Method}

material

$\mathrm{TiO}_{2}$

ion exchang

the AG MP-500 (Bio-Rad) was used after a preliminary treatment

in $5 \mathrm{M} \mathrm{HNO}_{3}$ and rinsing with $\mathrm{H}_{2} \mathrm{O}$. Ti(IV) was poorly sorbed.

Subsequently, scandium was eluted using ammonium acetate

solvent extraction

tri-n-butylphosphate (TBP) was used with an equal volume of 8

$\mathrm{N} \mathrm{HCl}$, washed with $\mathrm{H}_{2} \mathrm{O}$ and a $6 \%$ of carbonate solution. Equal volumes of aqueous phase of ion solution and TBP were used.

Cupferron (ammonium salt of the conjugate base derived from $\mathrm{N}$-nitroso-N-phenylhydroxylamine) was also used and Ti(IV) was extracted as cupferrate by $100 \%$ chloroform, Sc was separated from Ti by "gravity" with $98 \%$ of Sc extracted

extraction chromatography

tri-n-butylphosphate (TBP) was used with an equal volume of 8

$\mathrm{N} \mathrm{HCl}$, washed with $\mathrm{H}_{2} \mathrm{O}$ and a $6 \%$ of carbonate solution. Equal volumes of the aqueous phase of ion solution and TBP were used. TBP sorbed onto silica showed that $97.7 \%$ of Sc(III) were eluted with $2 \mathrm{~mL}$ of $\mathrm{HCl} 0.1 \mathrm{~N}$. No titanium was detected in the final samples

extraction chromatography

DGA resin could be used for Ti/Sc trace separations in the context of a fine purification of ${ }^{44} \mathrm{Ti}$ from the residual scandium target material. By contrast, $\mathrm{ZR}^{\oplus}$ resin was shown to exhibit a high sorption affinity for titanium, whereas scandium could be eluted with $\mathrm{HCl}$ solutions. Nonetheless, there are some drawbacks concerning this generator since some breakthrough of ${ }^{44} \mathrm{Ti}$ has been observed after several bed elutions.

$\mathrm{Ti}(0)$

extraction chromatography

Dissolution in $\mathrm{NH}_{4} \mathrm{HF}_{2}$

Elution on a branched DGA resin, recovery of scandium $88 \%$

$\mathrm{CaCO}_{3}$

extraction chromatography

target dissolved in $\mathrm{HCl}$ solution, passed through a UTEVA ${ }^{\circledR}$ resin

column and the column washed with $\mathrm{HCl}$. The scandium

radionuclides were eluted with $\mathrm{H}_{2} \mathrm{O}$. Efficiency $80 \%$

extraction chromatography

dissolving the $\mathrm{CaCO}_{3}$ targets in $\mathrm{HCl}$ solution, passed through a

$\mathrm{DGA}^{\oplus}$ resin with $\mathrm{HCl}$. Afterwards, the acidic ${ }^{47} \mathrm{SC}$ solution was

passed throught SCX cation exchange cartridges cation and

eluted with $\mathrm{HCl}$. Efficiency 93\%

extraction chromatography

dissolving the $\mathrm{CaCO}_{3}$ targets in $\mathrm{HCl}$ solution, passed through a DGA ${ }^{\oplus}$ resin with $\mathrm{HCl}$. Afterwards, the acidic ${ }^{43} \mathrm{SC}$ or ${ }^{44} \mathrm{SC}$ solution was loaded on a column filled with DOWEX50 cation exchange resin and ${ }^{43} \mathrm{SC}$ or ${ }^{44} \mathrm{Sc}$ was eluted using ammonium acetate solution at $\mathrm{pH}=4$. Efficiency $75 \%$

lon exchange

dissolution of the target in $\mathrm{HCl}$ and adsorption of ${ }^{43} \mathrm{SC}$ or ${ }^{44} \mathrm{SC}$ and even ${ }^{47} \mathrm{SC}$ onto a chelating ion exchange resin Chelex 100 After adsorption of Sc, the column was washed with $0.01 \mathrm{M} \mathrm{HCl}$ to remove $\mathrm{Ca}^{2+}$, scandium was eluted with $1 \mathrm{M} \mathrm{HCl}$. Efficiency $70 \%$

extraction chromatography

loading the dissolved target acidic solution onto DGA ${ }^{\oplus}$; rinsed in $4 \mathrm{M} \mathrm{HCl} ; \mathrm{HCl}$ was then necessary to elute quantitatively

scandium from the DGA ${ }^{\oplus}$ resin. Efficiency $95 \%$

extraction chromatography

dissolution of the target in $9 \mathrm{M} \mathrm{HCl}$, loaded on TBP resin

column, ${ }^{47} \mathrm{Sc}$ eluted with $\mathrm{H}_{2} \mathrm{O}$. Than loaded onto a BioRad

AG50WX4 resin, washed with $\mathrm{HCl} 0.1 \mathrm{M}$ and $\mathrm{H}_{2} \mathrm{O} ;{ }^{47} \mathrm{SC}$ was

eluted with portions of $1 \mathrm{M}$ sodium acetate solution at $\mathrm{pH} 4.5$.

Separation yield 52-79\%

\section{Reference}

(Pietrelli et al. 1992)

(Pietrelli et al. 1992; Valdovinos

et al. 2015

(Pietrelli et al. 1992)

(Majkowska-Pilip and Bilewicz 2011)

(Polosak et al. 2013; Loveless et al. 2019b)

(Valdovinos et al. 2015; Muller et al. 2014)

(Domnanich et al. 2017a)

(van der Meulen et al. 2015; Muller et al. 2014; van der Meulen et al. 2020)

(Walczak et al. 2015; Krajewski et al. 2013; Gizawy et al. 2020)

(Chaple and Lapi 2018; Alliot et al., 2015a; Filosofov et al. 2010)

(Rotsch et al. 2018) 
Table 3 Separation methods related to the initial target material for getting scandium radionuclides (Continued)

\begin{tabular}{|c|c|c|}
\hline \multirow[t]{7}{*}{$\begin{array}{l}\text { Starting } \\
\text { material }\end{array}$} & Separation Method & Reference \\
\hline & $\begin{array}{l}\text { extraction chromatography } \\
\text { target dissolved in } 11 \mathrm{M} \mathrm{HCl} \text { solution, passed through a UTEVA } \\
\text { resin column. Scandium radionuclides were eluted with } \mathrm{H}_{2} \mathrm{O} \\
\text { and loaded on a BioRad AG50WX4 resin, washed with } \mathrm{HCl} 0.1 \mathrm{M} \\
\text { and }{ }^{44} \mathrm{SC} \text { was eluted with portions of } 1 \mathrm{M} \text { sodium acetate } \\
\text { solution at pH } 4.5 \\
\text { Separation yield } 93.5 \%\end{array}$ & (Muller et al. 2018) \\
\hline & $\begin{array}{l}\text { extraction chromatography } \\
\text { dissolution of the target in } 1 \mathrm{~mL} 2 \mathrm{M} \mathrm{HCl} \text {, partial neutralization } \\
\text { with } 0.7 \mathrm{~mL} 1 \mathrm{M} \mathrm{NaOH}, \mathrm{pH} \text { adjustment with } \mathrm{pH} 3 \text { formate buffer } \\
\text { loading on Nobias } \mathrm{PA}-1 \text { (iminobisacetic acid-ethylenediamine- } \\
\text { triacetic acid chelate resin) resin column, washing with } 2 \mathrm{~mL} \text { for- } \\
\text { mate buffer, } \mathrm{pH} 3 \text {, } \\
\text { elution with } 0.1 \mathrm{~mL} 2 \mathrm{M} \mathrm{HCl} \text {, separation yield: } 95 \%\end{array}$ & (Kilian et al. 2018) \\
\hline & $\begin{array}{l}\text { Precipitation } \\
\text { calcium target dissolved with } 2 \mathrm{M} \mathrm{HCl} \text {, pH adjusted to } 6.5-9.0 \text { by } \\
\text { addition of } 1 \mathrm{M} \mathrm{NH}_{4} \mathrm{OH} \text {, solution pushed through a } 0.22 \mu \mathrm{m} \\
\text { Millex-GV } 13 \mathrm{~mm} \text { diameter syringe filter washed with } 10 \mathrm{~mL} 0.1 \\
\mathrm{M} \mathrm{NH}_{4} \mathrm{OH} \text { adjusted to pH } 8-9 \text { with } \mathrm{HCl} \text {. }\end{array}$ & (Severin et al. 2012) \\
\hline & $\begin{array}{l}\text { extraction chromatography } \\
\text { target dissolved in } \mathrm{HCl} \text { solution, }{ }^{44} \mathrm{Sc} \text { was separated from excess } \\
\text { of calcium by precipitation of scandium hydroxide using } \\
\text { ammonia. } \\
\text { passed through a UTEVA } \\
\text { with } \mathrm{HCl} \text {. The scandium column and the column washed } \\
\text { Efficiency } 80 \%\end{array}$ & (Wojdowska 2019) \\
\hline & $\begin{array}{l}\text { electroamalgamation } \\
\text { selective electroamalgamation of } \mathrm{Ca}^{2+} \text { ions }\end{array}$ & (Chakravarty et al. 2017) \\
\hline & $\begin{array}{l}\text { precipitation } \\
\text { Dissolution of the target in } 1 \mathrm{M} \mathrm{HCl} \text {, then alkalized with } 25 \% \\
\text { ammonia. Method takes advantage of the insolubility of } \mathrm{Sc}(\mathrm{OH})_{3} \\
\text { either as a precipitate or coprecipitate, which can be separated } \\
\text { from calcium by using microfilters with PTFE membrane } \\
(0.22 \mu \mathrm{m})\end{array}$ & $\begin{array}{l}\text { (Minegishi et al. 2016; Severin } \\
\text { et al. 2012; Duval and Kurbatov } \\
\text { 1953) }\end{array}$ \\
\hline
\end{tabular}

However, calcium doesn't form gaseous compounds near room temperature and atmospheric pressure, hence commonly used enrichment schemes such as gas centrifuge or thermal diffusion are not strictly impossible, but challenging. On the other hand methods based on liquid calcium forms, such as ion exchange chromatography or electrophoresis are difficult to scale up. Hence, enriched calcium materials are very expensive and a recycling process of the target needs to be developed (Jalilian et al., 2020). The choice of method used in the recovery process is related to the form of the initial target material, and it is particularly important when large amounts of the highly enriched target material are used. The recycling will contribute to a significant cost reduction, considering that the target material alone costs around $20-25 €$ per 1 mge (mg element) of $\left[{ }^{44} \mathrm{Ca}\right] \mathrm{CaCO}_{3}$ dependig on the purchased quantity (price for 2020). Additionally, the purchased material needs to be purified before use so the method for recycling applies here as well.

The published data on this topic is quite limited. Few publications deal with the calcium carbonate targets (natural or enriched in ${ }^{44} \mathrm{Ca}$ ) for production of ${ }^{44} \mathrm{Sc}$ in cyclotrons. One of the early works by Krajewski et al. (Krajewski et al. 2013) reported the use of chelating resin Chelex 100 for separation of ${ }^{44} \mathrm{Sc}$ and target recycling efficiency of only $60 \%$. In the work by Alliot et al. (Alliot et al. 2015a), using the mixture 
bicarbonate/methanol, the rate of solvent evaporation was increased and the solubility of calcium carbonate was lowered (Kan et al. 2002). The recovery yield of enriched calcium of $90 \pm 2 \%$ was obtained when starting with $\mathrm{CaCO}_{3}$ material and the $\mathrm{HCl}$ solutions from the extraction process. The solution was then loaded on a pre-conditioned AG1 $\times 8$ column to retain all metallic impurities $(\mathrm{Cu}, \mathrm{Co}, \mathrm{Fe} . .$.$) and enriched { }^{44} \mathrm{Ca}$ was rinsed in $9 \mathrm{M} \mathrm{HCl}$. This solution was evaporated to dryness and the dry residue recovered in a mixture of bicarbonate buffer $(\mathrm{pH}=10.33) /$ methanol, filtered and the residue dried in an oven at $105^{\circ} \mathrm{C}$ to remove water and methanol. The recycled targets were irradiated, and no significant difference in production yield was observed (Alliot et al. 2015a). The improved recovery reaching $98 \%$ of the initial enriched material, significantly reducing the operational costs, was reported by Van der Muelen et al. (van der Meulen et al. 2015) who collected effluents from the DGA column and recycled enriched calcium through simple and fast precipitation as Ca-oxalate, which was then converted to carbonate by slow heating to $500^{\circ} \mathrm{C}$. Alternatively, the final step involved heating at $900^{\circ} \mathrm{C}$ to ensure conversion to $\mathrm{CaO}$. It was shown that recycled material could be used effectively for ${ }^{44} \mathrm{Sc}$ production (van der Meulen et al. 2020). In the production of ${ }^{47} \mathrm{Sc}$ with alpha beams Minegishi et al. (Minegishi et al. 2016) recycled enriched target, collected as ${ }^{44} \mathrm{Ca}^{2+}$ in the waste fraction via the precipitation with ammonium carbonate and further dehydration to ${ }^{44} \mathrm{CaO}$ by decomposition of ${ }^{44} \mathrm{CaCO}_{3}$ at $940{ }^{\circ} \mathrm{C}$ for $2 \mathrm{~h}$. The recovery rate of approximately $85-90 \%$ (by weight), with negligible loss.

When starting material is $\mathrm{TiO}_{2}$, the enriched titatnium may be recovered and reused. A simple procedure was developed that recovers around $98.5 \%$ of the oxide based on precipitation of titanium at basic $\mathrm{pH}$ followed by conversion of the oxide using higher temperature (Kolsky et al. 1998). Other processes for recovery of titanium from its acidic solutions use either $\mathrm{HF}$ and $\mathrm{HNO}_{3}$ or converting to nano-sized titanium dioxide (Kolsky et al. 1998). The use of $\mathrm{TiO}_{2}$ as a starting material and its recycling process have been reported by Loveless et al. (Loveless et al. 2019b). The $\mathrm{HCl}$ solution and $\mathrm{HNO}_{3}$ obtained from the extraction processes were collected and $\mathrm{NH}_{4} \mathrm{OH}$ at $\mathrm{pH} 8$ was added to precipitate $\mathrm{TiO}_{2}$. The precipitate was then heated for $4 \mathrm{~h}$ at $400{ }^{\circ} \mathrm{C}$. Optionally, the enriched titanium oxide can be reduced with calcium or calcium hydride, resulting in titanium pellets with low content of impurities (Lommel et al. 2013).

\section{Chelators for Sc}

Scandium with its ionic radius $\left(\mathrm{r}_{\mathrm{i}}\right) 74.5 \mathrm{pm}(\mathrm{CN}=6)$ is chemically similar to $\mathrm{Y}^{3+}$ and the heaviest lanthanides. Similarly to them, scandium is almost exclusively present in its compounds in the trivalent state. Therefore, ligands developed for these cations should be also suitable for chelating Sc. However, the chemistry of trivalent scandium has some differences compared to lanthanides; it is smaller (thus, harder and has a higher preference for hard oxygen donor ligands), and prefers donor numbers from six to eight (Kerdjoudj et al. 2016).

The multi-dentate ligands, which were already used in Gd(III)-based MRI contrast agents as well as for radiolanthanides, that is derivatives of DTPA or DOTA, were also the first choice for scandium chelation for medical applications (Mausner et al. 1995). The stability constant of Sc-DOTA complex was comparable to that for $\mathrm{Lu}^{3+}$ and 
heavier lanthanides but higher than those for $\mathrm{In}^{3+}$ and $\mathrm{Ga}^{3+}$. The ${ }^{13} \mathrm{C}$ NMR studies have shown that $\mathrm{Sc}$ (DOTA) similarly to $\mathrm{Lu}$ (DOTA) forms in solution complexes with eight-coordination geometry (Majkowska-Pilip and Bilewicz 2011) The stability constants of scandium(III) complexes DTPA and DOTA (log $K_{\text {ScL }} 27.43$ and 30.79 respectively) were determined from potentiometric and ${ }^{45} \mathrm{Sc}$ NMR spectroscopic data. Both complexes were fully formed even below $\mathrm{pH}$ 2. Complexation of DOTA with the $\mathrm{Sc}^{3+}$ ion was much faster than with trivalent lanthanides. Proton-assisted decomplexation of the $[\mathrm{Sc}(\text { dota })]^{-}$complex $\left(\tau_{1 / 2}=45 \mathrm{~h} ; 1 \mathrm{M}\right.$ aq. $\left.\mathrm{HCl}, 25^{\circ} \mathrm{C}\right)$ was much slower than that for $[\operatorname{Ln}(\text { dota })]^{-}$complexes (Pniok et al. 2014). Therefore, DOTA and its derivatives were assumed to be very suitable ligands for scandium radioisotopes (Pniok et al. 2014; Huclier-Markai et al. 2015).

Thermodynamic data for scandium(III) complexes with polyamino-polycarboxylic ligands, such as NOTA, EDTA or TETA have been determined using potentiometric titration and free ion selective radiotracer extraction (FISRE) method and the values of stability constants were found to be in the order TETA $<$ NOTA $<$ EDTA $<$ DTPA $<$ DOTA. (Huclier-Markai et al. 2011) DOTA derivatives with phosphinic/methylphosphonic acid pendant arms (i.e. $\mathrm{DO}_{3} \mathrm{~A} ; \mathrm{DO}_{3} \mathrm{AP}^{\mathrm{PrA}}, \mathrm{DO}_{3} \mathrm{AP}^{\mathrm{ABn}}$ ) were also investigated showing that the stability constants of the monophosphinate analogues were somewhat lower than that of the Sc(DOTA) complex. (Kerdjoudj et al. 2016) The thermodynamic stability constant of recently developed chelating agent AAZTA, Sc(AAZTA) was reported to be lower than that of $\mathrm{Sc}(\mathrm{DOTA})$ but the striking difference was observed on the radiochemical yield at $25{ }^{\circ} \mathrm{C}$ indicating that AAZTA quickly incorporated ${ }^{44} \mathrm{Sc}$ (Nagy et al. 2017a). The AAZTA derivative AAZTA ${ }^{5}$ (1,4-bis (carboxymethyl)-6-[bis (carboxymethyl)]amino-6-[pentanoic-acid]perhydro-1.4-diazepine) was synthesized representing a bifunctional version with a pentanoic acid at the carbon- 6 atom. $\left[{ }^{44} \mathrm{Sc}\right] \mathrm{Sc}$-AAZTA ${ }^{5}$ complexes as well as $\left[{ }^{44} \mathrm{Sc}\right] \mathrm{Sc}-\mathrm{AAZTA}{ }^{5}$-TOC were formed at room temperature within $5 \mathrm{~min}$ in the $\mathrm{pH}$ range 4 to 5.5 and were very stable (Sinnes et al. 2019). Another chelator, $\mathrm{H}_{4}$ pypa $\left(\mathrm{N}_{5} \mathrm{O}_{4}\right)$ has been shown to exhibit high complexation constant with $\mathrm{Sc}$ (log $\mathrm{K}=27$ ) as well as with $\mathrm{In}, \mathrm{Lu}, \mathrm{Y}$ and $\mathrm{La}$, as determined by potentiometric titration and UV spectrometry (Li et al. 2019a; Li et al. 2019b). Its radiolabeling could be performed at room temperature and in a quite wide range of $\mathrm{pH}$ values within $10 \mathrm{~min}$. Also, it has been conjugated to a Glu-urea-Lys based PSMA (prostate-specific membrane antigen, e.g. PSMA-617). When labelled with ${ }^{44} \mathrm{Sc}(\mathrm{pH}=4.5,30 \mathrm{~min} \mathrm{RT})$ this conjugate showed specific tumor uptake (4.86\% ID/g from ex vivo biodistribution, $8 \mathrm{~h}$ p.i.) without significant off-target uptake, except in the kidney. (Li et al. 2019b) Further search on chelators enabling Sc chelation at room temperature led to the development of the smallcavity triaza-macrocycle-based, picolinate-functionalized chelator $\mathrm{H}_{3}$ mpatcn. Spectroscopic and radiochemical studies established the [Sc(mpatcn)] complex as kinetically inert and appropriate for biological applications. As a proof-of-concept bifunctional conjugate targeting the prostate-specific membrane antigen (PSMA), picaga-DUPA, chelated ${ }^{44} \mathrm{Sc}$ to form $\left\{{ }^{44} \mathrm{Sc}\right\} \mathrm{Sc}$ (picaga)-DUPA at room temperature with an apparent molar activity of $60 \mathrm{MBq} \mu \mathrm{mol}^{-1}$ and formation of inert $R R R-\Lambda$ and SSS- $\Delta$-twist isomers. Sc(picaga)-DUPA exhibited a $K_{\mathrm{i}}$ of $1.6 \mathrm{nM}$ for PSMA and the ${ }^{44} \mathrm{Sc}$ labelled Sc(picaga)-DUPA revealed high-quality images in prostate cancer-bearing animals. $\mathrm{H}_{3}$ mpatcn and its bifunctional analogue picaga represent new additions to the chelator toolbox for the emerging ${ }^{44 / 47} \mathrm{Sc}$ theragnostic isotope pair as reported by Vaughn et al. 
(Vaughn et al. 2020a). Nonetheless, the molar activity calculated from their experimental data was estimated to be $0.03 \mathrm{MBq} / \mathrm{nmol}$ and thus the metal to ligand ratio was ranging between 1: 485,500 to $1: 1,084,600$. Hence, picagaDUPA seems exhibiting complexation/radiolabeling at RT but complexation constant must be established and the potential of this ligand to provide higher molar activity must be evaluated with sources of ${ }^{44} \mathrm{Sc}$ of high purity.

Scandium also displays favorable physical properties and chemistry for conjugation to mAb-chelate systems. Since it is chemically similar to ${ }^{90} \mathrm{Y}$ and close to ${ }^{177} \mathrm{Lu}$, the same ligands developed for ${ }^{90} \mathrm{Y}$ or ${ }^{177} \mathrm{Lu}$ can be used for chelating ${ }^{47} \mathrm{Sc}$.

Table 4 provides a summary of the main chelates that have been evaluated, with the corresponding formula and the measured value of the complexation constant with scandium. The table reports values reported in the original manuscripts, accuracy of which is not homogeneous across the data. For simplicity, the uncertainties (available only for selected studies) are not reported.

\section{Radiolabeling studies}

Labeling protocols should allow high labeling yields, radiochemical purity and molar activity (Fani and Maecke 2012). Labelling efficiency of ligands is usually tested at various $\mathrm{pH}$, temperature and ligand concentration (or more correctly, at different radiometal-to-ligand molar ratios) and is monitored as a function of time in order to optimize the radiolabeling. Herein, we discuss the development of labelling methods that were developed for scandium radionuclides. Neverthelles, the reported data are often difficult to compare. To overcome this problem, the recommendations on consensus nomenclature rules for radiopharmaceutical chemistry should be followed (Coenen et al. 2017).

Most of the published radiolabeling works have been done with ${ }^{44} \mathrm{Sc}$. All have highlighted the importance of reaching a high chemical purity of the final ${ }^{44} \mathrm{Sc}$ fraction before radiolabeling. The presence of other metals may interact with the DOTAchelator (or any other chelator) that can affect the radiolabeling yield. The content of environmental contaminants (i.e. $\mathrm{Al}(\mathrm{III}), \mathrm{Cu}(\mathrm{II}), \mathrm{Pb}(\mathrm{II}), \mathrm{Zn}(\mathrm{II}), \mathrm{Fe}(\mathrm{III}))$ in ${ }^{44} \mathrm{Sc}$ is frequent. The most problematic is $\mathrm{Fe}^{3+}$, for which the stability with the DOTA ligand is greater than that for $\mathrm{Sc}^{3+}$. By contrast, the influence of divalent metal cations (considered as contaminants) is negligible due to the lower stability of DOTA-divalent metal complexes. Although DOTA forms very stable complexes, it exhibits slow formation kinetics at room temperature, that could be increased by heating. However, elevated temperatures remain an important obstacle for efficient labelling of heat-sensitive molecules such as antibodies. Click-chemistry or the new ligands permitting the formation of scandium complexes with faster kinetics, or at much lower temperatures than that required for DOTA, might circumvent this issue. In this context, AAZTA or H4pypa seem to be interesting alternatives (Nagy et al. 2017a; Li et al. 2019a), although their availability is limited.

Table 5 provides a summary of the radiolabeling studies published to date. Notably, there are many discrepancies in presentation of results and in most of the cases the quality control results of the batches are not reported. When available, radiochemical yield and molar activity are indicated. This inhomogeneity of the published data makes 


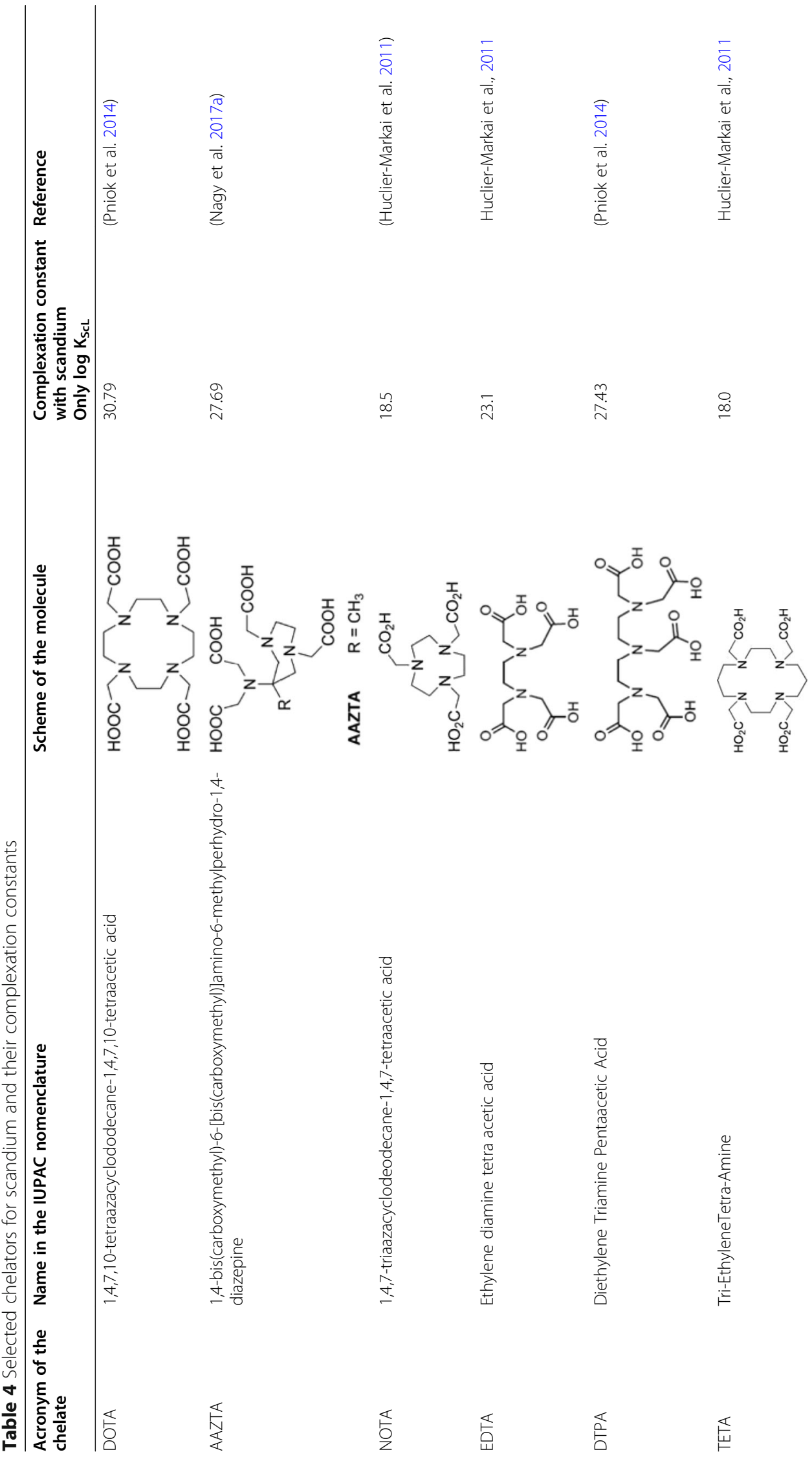




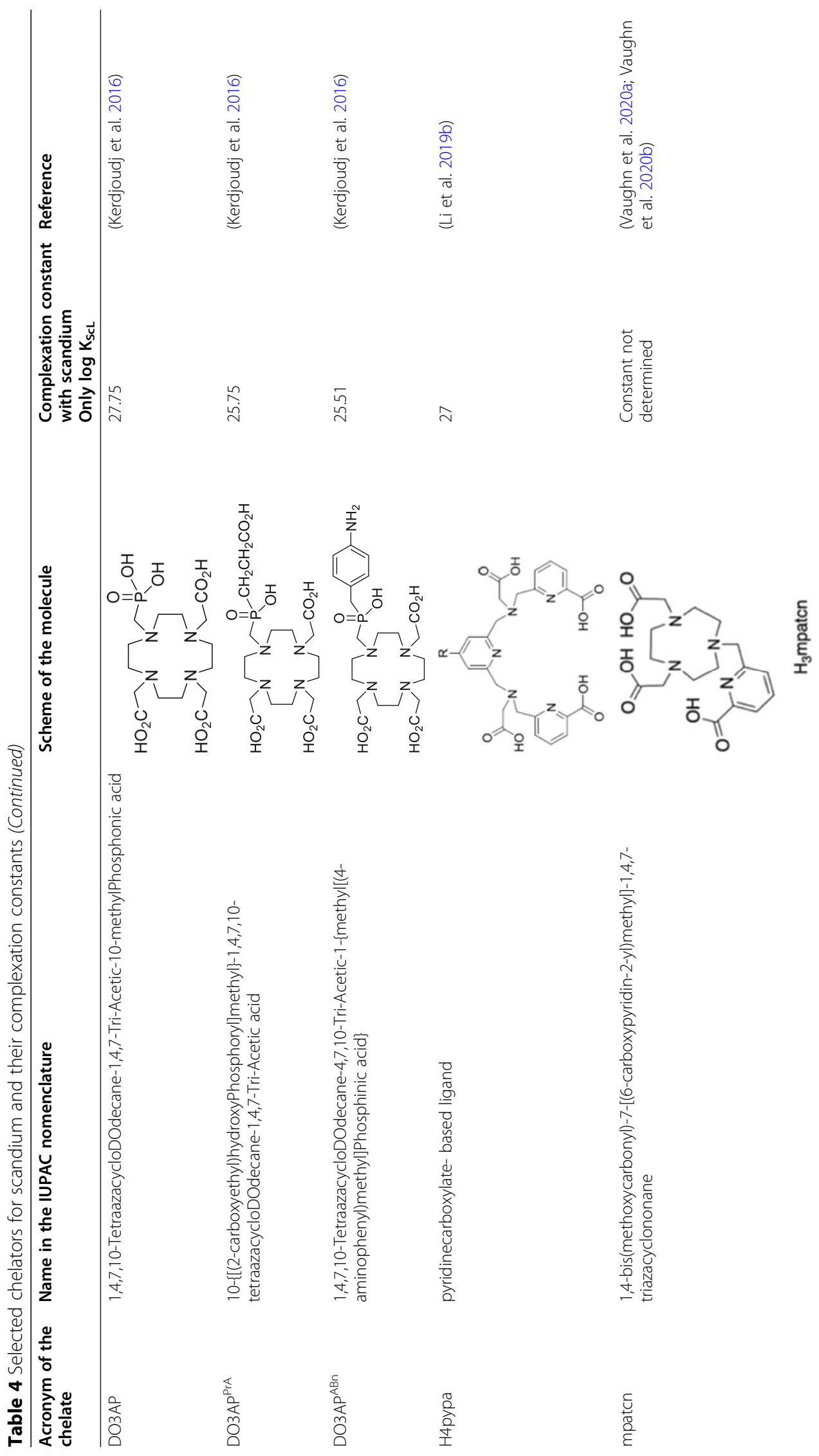




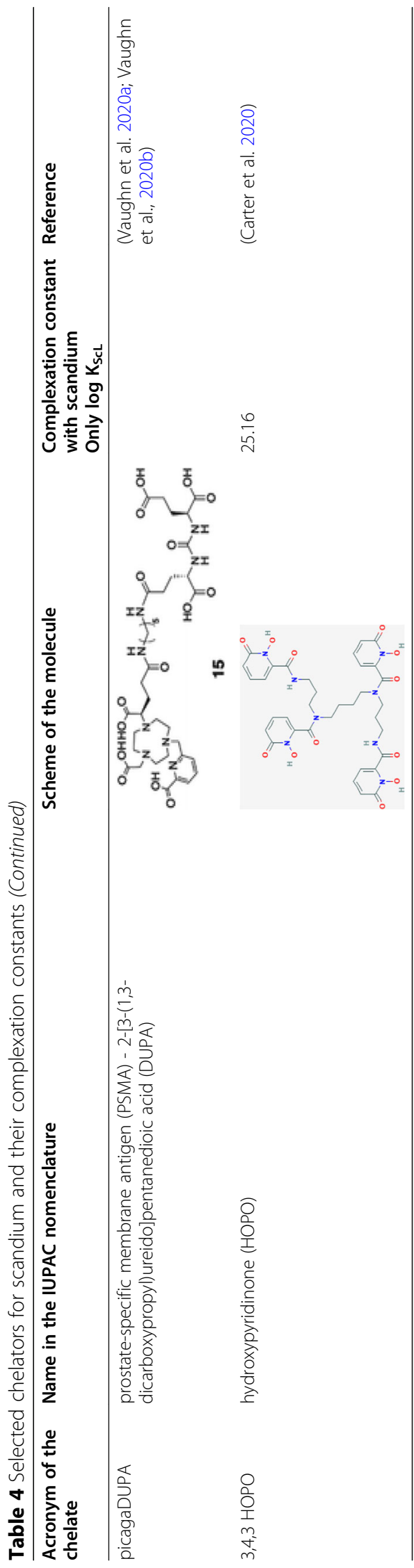


Table 5 Radiolabeling studies performed on scandium radionuclides

\begin{tabular}{|c|c|c|c|c|c|c|}
\hline $\begin{array}{l}\text { Type of } \\
\text { vector }\end{array}$ & $\begin{array}{l}\text { RN } \\
\text { used }\end{array}$ & $\begin{array}{l}\text { Buffer, } \mathrm{pH}, \\
\mathrm{T}^{\circ}, \text { time } \\
\text { conditions }\end{array}$ & $\begin{array}{l}\text { Quality Control / } \\
\text { RCY }\end{array}$ & Molar activity & $\begin{array}{l}\text { Post- } \\
\text { radiolabeling } \\
\text { purification }\end{array}$ & Reference \\
\hline DOTA & ${ }^{44} \mathrm{SC}$ & $\begin{array}{l}0.2 \mathrm{M} \\
\text { ammonium } \\
\text { acetate } \\
\mathrm{pH}=4.8 \\
80^{\circ} \mathrm{C} \\
30 \mathrm{~min}\end{array}$ & iTLC with $\mathrm{H}_{2} \mathrm{O}$ & $\begin{array}{l}51 \mathrm{GBq} / \mu \mathrm{mol} \\
\text { competitive } \\
\text { metal impurities } \\
\text { of } 28 \mu \mathrm{M} \\
\text { (mostly Fe) }\end{array}$ & Not indicated & $\begin{array}{l}\text { (Severin } \\
\text { et al. 2012) }\end{array}$ \\
\hline $\begin{array}{l}\text { DTPA } \\
\text { HEBD } \\
\text { BAPTA } \\
\text { EGTA } \\
\text { TTHA } \\
\text { DFO } \\
\text { DOTA }\end{array}$ & ${ }^{47} \mathrm{SC}$ & $\begin{array}{l}20 \mathrm{mM} \\
\text { acetate } \\
\text { buffer } \\
\mathrm{pH}=6.0 \\
\text { RT }\end{array}$ & $\begin{array}{l}\text { iTLC } \\
\text { with } \mathrm{NH}_{3} / \mathrm{H}_{2} \mathrm{O}(1 / \\
25) \\
\text { DTPA } \\
\text { RCY }=38.8-100 \% \\
\text { EGTA } \\
\text { RCY }=97.2-100 \% \\
\text { DOTA } \\
\text { RCY }=79.4-97.7 \%\end{array}$ & $\begin{array}{l}\text { Estimation } \\
0.017 \mathrm{MBq} / \mathrm{nmol}\end{array}$ & Not performed & $\begin{array}{l}\text { (Severin } \\
\text { et al. 2012; } \\
\text { Polosak et al. } \\
\text { 2013) }\end{array}$ \\
\hline picagaDUPA & ${ }^{44} \mathrm{SC}$ & $\begin{array}{l}0.25 \mathrm{M} \\
\mathrm{NaOAC} \\
\text { buffer } \\
\text { solution } \\
\mathrm{pH}=4 \\
\text { at } 25 \text { or } \\
80^{\circ} \mathrm{C} \text {. }\end{array}$ & $\begin{array}{l}\text { TLC } \\
\text { with } 50 \mathrm{mM} \text { EDTA } \\
\text { RCY }=83 \% \text { at } 25^{\circ} \mathrm{C} \\
\text { RCY }=96 \% \text { at } 80^{\circ} \mathrm{C}\end{array}$ & $\begin{array}{l}\text { Calculated from } \\
\text { (Polosak et al. } \\
\text { 2013) } 0.03 \mathrm{MBq} / \\
\text { nmol }\end{array}$ & Not performed & $\begin{array}{l}\text { (Vaughn } \\
\text { et al. 2020a) }\end{array}$ \\
\hline $\begin{array}{l}\text { AAZTA- } \\
\text { c(RGDfK) }\end{array}$ & ${ }^{44} \mathrm{SC}$ & $\begin{array}{l}0.25 \mathrm{M} \\
\text { ammonium } \\
\text { acetate } \\
\mathrm{pH}=4 \\
\text { room } \\
\text { temperature } \\
5 \text { min }\end{array}$ & $\mathrm{RCY}=99 \%$ & $0.36 \mathrm{GBq} / \mu \mathrm{mol}$ & & $\begin{array}{l}\text { (Nagy et al. } \\
2017 a ; \\
\text { Vaughn } \\
\text { et al. 2020a; } \\
\text { Kostelnik } \\
\text { and Orvig } \\
\text { 2019) }\end{array}$ \\
\hline $\begin{array}{l}\text { Propargyl- } \\
\text { DOTA }\end{array}$ & ${ }^{44} \mathrm{SC}$ & $\begin{array}{l}95^{\circ} \mathrm{C} \text { for } 30 \\
\min \end{array}$ & $\begin{array}{l}\text { HPLC } \\
\text { Phenomenex } \\
\text { Synergi, } 4 \mu, \\
\text { Hydro-RP, } 80 \AA \\
\text { a gradient with } \\
\text { the eluents } \\
\text { acetonitrile (A) } \\
\text { and } \mathrm{H}_{2} \mathrm{O}(\mathrm{B}), \text { both } \\
\text { containing } 0.1 \% \\
\text { trifluoroacetic acid } \\
\text { and a flow rate of } \\
1.0 \mathrm{~mL} / \mathrm{min} \text {. } \\
\mathrm{RCY}=69-92 \%\end{array}$ & $\begin{array}{l}\text { Other metals: } \\
\mathrm{Zn}(5.4 \pm 4.5 \\
\mathrm{ppm}), \mathrm{Fe}(1.1 \pm \\
0.7 \mathrm{ppm}), \mathrm{Pb} \\
(0.38 \pm 0.13 \\
\mathrm{ppm}) \text { and } \mathrm{Al} \\
(0.18 \pm 0.14 \\
\mathrm{ppm})\end{array}$ & Not performed & $\begin{array}{l}\text { (Hoehr et al. } \\
\text { 2014) }\end{array}$ \\
\hline $\begin{array}{l}\text { DOTA - } \\
\text { puromycin }\end{array}$ & ${ }^{44} \mathrm{SC}$ & $\begin{array}{l}0.25 \mathrm{M} \\
\text { ammonium } \\
\text { acetate } \\
\mathrm{pH}=4 \\
95^{\circ} \mathrm{C} \\
20 \mathrm{~min}\end{array}$ & $\begin{array}{l}\text { iTLC } \\
\text { Elution with n- } \\
\text { propanol/ } \mathrm{NH}_{4} \mathrm{OH} / \\
\mathrm{H}_{2} \mathrm{O}(55: 35: 10) \\
\mathrm{RCY}=78 \%\end{array}$ & $1.5 \mathrm{GBq} / \mu \mathrm{mol}$ & $\begin{array}{l}\text { HPLC - C-18 cart- } \\
\text { ridge (Strata-X } \\
\text { Polymeric Sorbet } \\
60 \mathrm{mg} / \mathrm{mL} \\
\text { Phenomenex) } \\
\text { Elution with } \\
\text { ethanol } \\
\text { Radiochemical } \\
\text { purity } \geq 97 \%\end{array}$ & $\begin{array}{l}\text { (Eigner et al. } \\
\text { 2013) }\end{array}$ \\
\hline $\begin{array}{l}\text { DOTA- } \\
\text { Folate }\end{array}$ & ${ }^{44} \mathrm{SC}$ & $\begin{array}{l}1 \mathrm{M} \\
\text { ammonium } \\
\text { acetate } \\
\mathrm{pH} 3.5-4 \\
95^{\circ} \mathrm{C} \\
10 \text { min }\end{array}$ & $\begin{array}{l}\text { HPLC - C-18 col- } \\
\text { umn (Xterra MS } \\
\text { C18, Waters). } \\
\text { Mobile phase: Milli } \\
\text { Q water with 0.1\% } \\
\text { trifluoracetic acid } \\
\text { (A) and methanol } \\
\text { (B) with a linear } \\
\text { gradient from 95\% } \\
\text { A and 5\% B to } \\
20 \% \text { A and } 80 \% \text { B } \\
\text { over } 25 \text { min with a }\end{array}$ & $\begin{array}{l}\geq 5.2 \mathrm{MBq} / \\
\text { nmol, } \\
\text { representing a } \\
44 \mathrm{Sc}-\text { to-ligand } \\
\text { molar ratio of } 1 \text { : } \\
5600\end{array}$ & Not indicated & $\begin{array}{l}\text { (Muller et al. } \\
\text { 2018) }\end{array}$ \\
\hline
\end{tabular}


Table 5 Radiolabeling studies performed on scandium radionuclides (Continued)

\begin{tabular}{|c|c|c|c|c|c|c|}
\hline $\begin{array}{l}\text { Type of } \\
\text { vector }\end{array}$ & $\begin{array}{l}\text { RN } \\
\text { used }\end{array}$ & $\begin{array}{l}\text { Buffer, } \mathrm{pH}, \\
\mathrm{T}^{\circ}, \text { time } \\
\text { conditions }\end{array}$ & $\begin{array}{l}\text { Quality Control / } \\
\text { RCY }\end{array}$ & Molar activity & $\begin{array}{l}\text { Post- } \\
\text { radiolabeling } \\
\text { purification }\end{array}$ & Reference \\
\hline & & & $\begin{array}{l}\text { flow rate of } 1 \mathrm{~mL} / \\
\min \\
R C Y \geq 96 \%\end{array}$ & & & \\
\hline & ${ }^{47} \mathrm{SC}$ & $\begin{array}{l}\mathrm{CH}_{3} \mathrm{COONH}_{4} / \\
\mathrm{HCl} \\
\mathrm{pH} 4.5 \\
95^{\circ} \mathrm{C} \\
10 \mathrm{~min}\end{array}$ & $\begin{array}{l}\mathrm{HPLC} \text { as above } \\
\mathrm{RCY} \geq 96 \%\end{array}$ & $\begin{array}{l}\text { no radionuclidic } \\
\text { impurities were } \\
\text { detectable } \\
13 \mathrm{MBq} / \mathrm{nmol}\end{array}$ & Not indicated & $\begin{array}{l}\text { (Muller et al. } \\
\text { 2014) }\end{array}$ \\
\hline PSMA-617 & ${ }^{44} \mathrm{SC}$ & $\begin{array}{l}0.25 \mathrm{M} \\
\text { ammonium } \\
\text { acetate } \\
\mathrm{pH}=4 \\
95^{\circ} \mathrm{C} \\
25 \mathrm{~min}\end{array}$ & $\begin{array}{l}\text { iTLC 1:1 v/v } 1 \mathrm{M} \\
\text { ammonium } \\
\text { acetate / } \\
\text { methanol } \\
\text { RCY = 74\%- 98\% }\end{array}$ & $\begin{array}{l}1.82-6.69 \mathrm{MBq} / \\
\mathrm{nmol}\end{array}$ & $\begin{array}{l}\text { HPLC - C-18 cart- } \\
\text { ridge (Sep-Pak } \\
\text { C18 Plus Short } \\
\text { Waters) - after a } \\
\text { pre-conditioning } \\
\text { with } 4 \mathrm{~mL} \text { of etha- } \\
\text { nol and } 10 \mathrm{~mL} \text { of } \\
\text { water. Elution with } \\
\text { pure ethanol. }\end{array}$ & $\begin{array}{l}\text { (Eppard } \\
\text { 2018) }\end{array}$ \\
\hline \multirow[t]{2}{*}{ DOTANOC } & ${ }^{44} \mathrm{SC}$ & $\begin{array}{l}0.2 \mathrm{M} \text { sodium } \\
\text { acetate } \\
\text { buffer } \\
\mathrm{pH} 4 \\
85^{\circ} \mathrm{C} \\
15 \mathrm{~min}\end{array}$ & $\begin{array}{l}\text { HPLC C-18 (Xter- } \\
\text { raTM MS column } \\
95 \% \text { MilliQ water } \\
\text { with } 0.1 \% \text { trifluora- } \\
\text { cetic acid (A) and } \\
5 \% \text { acetonitrile (B) } \\
\text { over a } 20 \text {-min } \\
\text { period at a flow } \\
\text { rate of } 1 \mathrm{~mL} / \mathrm{min} \\
\mathrm{RCY} \geq 98 \%\end{array}$ & & Not indicated & $\begin{array}{l}\text { (van der } \\
\text { Meulen et al. } \\
\text { 2015) }\end{array}$ \\
\hline & ${ }^{47} \mathrm{SC}$ & $\begin{array}{l}0.5 \mathrm{M} \text { sodium } \\
\text { acetate } \\
\mathrm{pH} 4.5 \\
95^{\circ} \mathrm{C} \\
15 \mathrm{~min}\end{array}$ & $\begin{array}{l}\text { HPLC C-18 (Xter- } \\
\text { raTM MS column } \\
95 \% \text { MilliQ water } \\
\text { with } 0.1 \% \text { trifluora- } \\
\text { cetic acid (A) and } \\
5 \% \text { acetonitrile (B) } \\
\text { over a } 20 \text {-min } \\
\text { period at a flow } \\
\text { rate of } 1 \mathrm{~mL} / \mathrm{min} \\
\mathrm{RCY} \geq 96 \%\end{array}$ & $\begin{array}{l}\text { 10-25 MBq/ } \\
\mathrm{nmol}\end{array}$ & Not indicated & $\begin{array}{l}\text { (Domnanich } \\
\text { et al. 2017a) }\end{array}$ \\
\hline \multirow[t]{2}{*}{ DOTATOC } & ${ }^{44} \mathrm{SC}$ & $\begin{array}{l}0.8 \mathrm{M} \\
\text { ammonium } \\
\text { acetate } \\
\mathrm{pH}=5 \\
91{ }^{\circ} \mathrm{C} \\
30 \mathrm{~min}\end{array}$ & $\begin{array}{l}\mathrm{iTLC} \\
\mathrm{RCY}=99 \%\end{array}$ & $1.4 \mathrm{MBq} / \mu \mathrm{g}$ & Not indicated & $\begin{array}{l}\text { (Singh et al. } \\
\text { 2017) }\end{array}$ \\
\hline & ${ }^{44} \mathrm{SC}$ & $\begin{array}{l}0.25 \mathrm{M} \\
\text { ammonium } \\
\text { acetate } \\
\mathrm{pH}=4 \\
95^{\circ} \mathrm{C} \\
30 \mathrm{~min}\end{array}$ & $\begin{array}{l}\text { iTLC } \\
\text { a) } 0.1 \mathrm{M} \text { sodium } \\
\text { citrate } \mathrm{pH} 4.0 \\
\text { (b) mixture of } 5 \% \\
\mathrm{NaCl} \text { with } \mathrm{MeOH} \\
\text { (3:1) } \\
\text { (c) mixture of } 5 \% \\
\mathrm{NaCl} \text { with } \mathrm{MeOH} \\
\text { and } 25 \% \mathrm{NH}_{3}(3: 1 \text { : } \\
\text { 1) } \\
\mathrm{RCY} \geq 98 \%\end{array}$ & $9 \mathrm{GBq} / \mathrm{\mu mol}$ & $\begin{array}{l}\text { Performed on RP } \\
\text { C-18 mini- } \\
\text { cartridge Strata-X } \\
\text { Elution with pure } \\
\text { ethanol }\end{array}$ & $\begin{array}{l}\text { (Kerdjoudj } \\
\text { et al. 2016) }\end{array}$ \\
\hline \multirow[t]{2}{*}{ DOTATATE } & ${ }^{44 \mathrm{~m} / 44} \mathrm{SC}$ & $\begin{array}{l}0.1 \mathrm{M} \\
\text { ammonium } \\
\text { acetate } \\
\mathrm{pH} \mathrm{4-6} \\
70^{\circ} \mathrm{C} \\
20 \mathrm{~min}\end{array}$ & $\begin{array}{l}\text { TLC } \\
25 \% \text { aq. } \mathrm{NH}_{3} / \mathrm{H}_{2} \mathrm{O} / \\
\mathrm{MeOH}, 2 / 1 / 1(\mathrm{v} / \mathrm{V}) \\
\mathrm{RCY} \geq 95 \%\end{array}$ & $\begin{array}{l}8 \mathrm{MBq} / \mathrm{nmol} \\
\text { radionuclidic } \\
\text { purity }=99 \%\end{array}$ & Not performed & $\begin{array}{l}\text { (Huclier- } \\
\text { Markai et al. } \\
\text { 2018; Alliot } \\
\text { et al. 2015a; } \\
\text { Alliot et al. } \\
\text { 2015b) }\end{array}$ \\
\hline & ${ }^{43} \mathrm{SC}$ & $\begin{array}{l}\text { ammonium } \\
\text { acetate }\end{array}$ & $\begin{array}{l}\text { TLC } \\
0.1 \mathrm{M} \text { sodium }\end{array}$ & Not indicated & Not performed & $\begin{array}{l}\text { (Szkliniarz } \\
\text { et al. 2016) }\end{array}$ \\
\hline
\end{tabular}


Table 5 Radiolabeling studies performed on scandium radionuclides (Continued)

\begin{tabular}{|c|c|c|c|c|c|c|}
\hline $\begin{array}{l}\text { Type of } \\
\text { vector }\end{array}$ & $\begin{array}{l}\text { RN } \\
\text { used }\end{array}$ & $\begin{array}{l}\text { Buffer, pH, } \\
\mathrm{T}^{\circ}, \text { time } \\
\text { conditions }\end{array}$ & $\begin{array}{l}\text { Quality Control / } \\
\text { RCY }\end{array}$ & Molar activity & $\begin{array}{l}\text { Post- } \\
\text { radiolabeling } \\
\text { purification }\end{array}$ & Reference \\
\hline & & $\begin{array}{l}\mathrm{pH}=5 \\
90^{\circ} \mathrm{C} \\
35 \mathrm{~min}\end{array}$ & $\begin{array}{l}\text { citrate }(\mathrm{pH}=5.0) \\
\mathrm{RCY}=98.3 \%\end{array}$ & & & \\
\hline $\begin{array}{l}\text { CHX-A"- } \\
\text { DTPA-Fab } \\
\text { fragment of } \\
\text { Cetuximab }\end{array}$ & ${ }^{44} \mathrm{SC}$ & $\begin{array}{l}0.5 \mathrm{M} \text { sodium } \\
\text { acetate } \\
\text { buffer } \\
\text { pH } 6.5 \\
\text { adjusted to } \\
\sim 4.5 \\
\text { room } \\
\text { temperature } \\
\left(25^{\circ} \mathrm{C}\right) \\
30 \mathrm{~min}\end{array}$ & $\begin{array}{l}\text { TLC } \\
50 \% \text { aqueous } \\
\text { acetonitrile }\end{array}$ & $63 \mathrm{GBq} / \mathrm{\mu mol}$ & $\begin{array}{l}\text { PD-10 columns } \\
\text { PBS as the mobile } \\
\text { phase }\end{array}$ & $\begin{array}{l}\text { (Chakravarty } \\
\text { et al. 2014) }\end{array}$ \\
\hline $\begin{array}{l}\text { DOTA } \\
\text {-Z HER2-2891 }\end{array}$ & ${ }^{44} \mathrm{SC}$ & & $\mathrm{RCY}=98 \%$ & $7.8 \mathrm{GBq} / \mu \mathrm{mol}$ & & $\begin{array}{l}\text { (Honarvar } \\
\text { et al. 2017) }\end{array}$ \\
\hline
\end{tabular}

the direct comparison of radiotracers efficacy difficult. The data in Table 5 are reported as published in the original papers, pointing to the discrepancies in the measurement units used. Indications on the quality control procedure are also given as well as the conditions of post-radiolabeling purification, wherever reported. The use of suitable buffers, stabilizers/free radical scavengers etc. was addressed.

\section{Pre-clinical studies}

The use of radiolabeled compounds for in vitro and in vivo preclinical animal studies has steadily increased in recent years, becoming a much more widely used method for studying biochemistry, physiology and pharmacology (Kilbourn and Scott 2018). The increasing availability of ${ }^{44} \mathrm{Sc}$ and its compatibility with numerous chelators, among those DOTA, has led to multiple studies in animals, especially imaging studies. The half-lives of ${ }^{43} \mathrm{Sc},{ }^{44} \mathrm{Sc}$ or ${ }^{47} \mathrm{Sc}$ are compatible with the pharmacokinetics of a fairly wide range of targeting vectors. Several somatostatin analogs, either DOTA-derivatized (DOTATOC, DOTATATE, DOTANOC) or with NODAGA as a chelator, have been labeled with scandium radionuclides to prove the suitability of the obtained radionuclide solution for radiolabeling (Pawlak et al. 2019; Loveless et al. 2019a) or to compare under the same conditions the in vitro/in vivo imaging/therapeutic potential of scandium radiolabeled peptides to their ${ }^{68} \mathrm{Ga}$ - or ${ }^{177} \mathrm{Lu}\left({ }^{90} \mathrm{Y}\right)$ - radiolabeled counterparts (Walczak et al. 2015; Loveless et al. 2019a; Singh et al. 2017; Pruszynski et al. 2012). The scandium radionuclides labeled bombesin analogs (Koumarianou et al. 2012), RGD peptides (Domnanich et al. 2017c), folate derivatives (Muller et al. 2018; Muller et al. 2014; Siwowska et al. 2019) and PSMA ligands (Umbricht et al. 2017) have been evaluated pre-clinically. Few studies have also reported on scandium radiolabeled antibodies, antibody fragments or affibodies (Chakravarty et al. 2014; Honarvar et al. 2017; Moghaddam-Banaem 2012) and nanoparticles (Eppard et al. 2018). A summary is given in Table 6.

The early study by Koumarianou et al. (Koumarianou et al. 2011) was conducted on "cold" complexes with natural scandium and gallium. The binding affinity of both ${ }^{\text {nat }}$ Sc-DOTATATE and ${ }^{\text {nat }}$ Ga-DOTATATE in AR42J cell line was in the sub- 
Table 6 Current state of pre-clinical studies performed on scandium radionuclides

\begin{tabular}{|c|c|c|c|c|c|}
\hline $\begin{array}{l}\text { Type of } \\
\text { vector }\end{array}$ & $\begin{array}{l}\text { Radioisotope } \\
\text { used }\end{array}$ & $\begin{array}{l}\text { Tumor model or } \\
\text { human }\end{array}$ & $\begin{array}{l}\text { Bio- } \\
\text { Distributions } \\
\text { (BioD) } \\
\text { PET images }\end{array}$ & Main results & Reference \\
\hline $\begin{array}{l}\text { DOTATATE } \\
\text { DOTANOC } \\
\text { DOTATOC }\end{array}$ & $\begin{array}{l}{ }^{\mathrm{nat}} \mathrm{SC}_{1}{ }^{43} \mathrm{SC}, \\
{ }^{44} \mathrm{SC}\end{array}$ & AR42J cells, $x x x$ & In vitro & & $\begin{array}{l}\text { (Walczak et al. 2015; } \\
\text { Minegishi et al. 2016; } \\
\text { Domnanich et al. } \\
\text { 2017b; Pruszynski } \\
\text { et al. 2012; } \\
\text { Domnanich et al. } \\
\text { 2017c; Koumarianou } \\
\text { et al. 2011) }\end{array}$ \\
\hline DOTATOC & ${ }^{47} \mathrm{SC}$ & AR42J cells & In vitro & & $\begin{array}{l}\text { (Loveless et al. } \\
\text { 2019a) }\end{array}$ \\
\hline $\begin{array}{l}\text { DOTA - } \\
\text { puromycin }\end{array}$ & ${ }^{44} \mathrm{SC}$ & $\begin{array}{l}\text { Walker carcinoma } \\
256 \text { (breast } \\
\text { carcinoma) in rats } \\
\text { AT1 carcinoma } \\
\text { (prostate } \\
\text { carcinoma) in rats }\end{array}$ & $\mathrm{BiOD}+\mathrm{PET}$ & $\begin{array}{l}\text { significant tumor } \\
\text { uptake of }\left[{ }^{44} \mathrm{Sc}\right] \mathrm{Sc}- \\
\text { DOTA puromycin and } \\
\text { a clear-cut tumor } \\
\text { visualization, cellular } \\
\left.\text { uptake of }{ }^{44} \mathrm{Sc}\right] \mathrm{Sc}- \\
\text { DOTA-puromycin } \\
\text { could be suppressed } \\
\text { by blocking protein } \\
\text { synthesis }\end{array}$ & (Eigner et al. 2013) \\
\hline $\begin{array}{l}\text { DOTA- } \\
\text { Bombesin }\end{array}$ & ${ }^{44} \mathrm{SC}^{6}{ }^{68} \mathrm{Ga}$ & $\begin{array}{l}\text { PC3 cells, rats with } \\
\text { Dunning R-3327- } \\
\text { AT-1 prostate can- } \\
\text { cer tumor (GRP/ } \\
\text { BN receptor } \\
\text { expression) } \\
\text { MCF7 }\end{array}$ & $\begin{array}{l}\text { BioD }+ \\
\text { microPET }\end{array}$ & $\begin{array}{l}{ }^{68} \mathrm{Ga}-\text { and }\left[{ }^{44} \mathrm{Sc}\right] \mathrm{Sc}- \\
\text { DOTA-BN[2-14]NH } \\
\text { showed no } \\
\text { differences in tumor } \\
\text { uptake in micro-PET } \\
\text { images } \\
\left.{ }^{68} \mathrm{Ga}\right] \mathrm{Ga}-\text { and } \\
{\left[{ }^{449} \mathrm{Sc}\right] \mathrm{Sc}-\mathrm{DOTA}-\mathrm{Av} \text { - }} \\
\text { BBN showed similar } \\
\text { accumulation and } \\
\text { retention profiles in } \\
\text { PC3 and MCF7 } \\
\text { tumors }\end{array}$ & $\begin{array}{l}\text { (Koumarianou et al. } \\
\text { 2012), (Ferguson } \\
\text { et al. 2020) }\end{array}$ \\
\hline \multirow[t]{2}{*}{$\begin{array}{l}\text { DOTA- } \\
\text { Folate }\end{array}$} & ${ }^{44} \mathrm{SC}$ & $\begin{array}{l}\text { KB cells } \\
\text { KB tumor-bearing } \\
\text { mice }\end{array}$ & BioD + PET & $\begin{array}{l}\text { Tissue accumulation is } \\
\text { similar to }\left[{ }^{177} \mathrm{Lu}\right] \mathrm{Lu}- \\
\text { folate }=>^{44} \mathrm{SC} \text { could } \\
\text { serve for dosimetry } \\
\text { prior to }{ }^{177} \mathrm{Lu} \text {-based } \\
\text { therapy }\end{array}$ & $\begin{array}{l}\text { (Muller et al. 2018; } \\
\text { Muller et al. 2014) }\end{array}$ \\
\hline & ${ }^{47} \mathrm{SC}$ & $\begin{array}{l}\text { KB cells } \\
\text { KB tumor-bearing } \\
\text { mice }\end{array}$ & BioD & $\begin{array}{l}\text { Delay in tumor } \\
\text { growth }\end{array}$ & $\begin{array}{l}\text { (Muller et al. 2014; } \\
\text { Siwowska et al. 2019) }\end{array}$ \\
\hline \multirow[t]{2}{*}{ PSMA-617 } & $\begin{array}{l}{ }^{44} \mathrm{SC}_{1}{ }^{177} \mathrm{Lu}, \\
{ }^{68} \mathrm{Ga}\end{array}$ & $\begin{array}{l}\text { PC-3 PIP and } \\
\text { PSMA-negative } \\
\text { PC-3 flu prostate } \\
\text { cancer cells }\end{array}$ & $\begin{array}{l}\text { BioD + PET } \\
(2 \text { h p.i. })\end{array}$ & $\begin{array}{l}{\left[{ }^{44} \text { Sc]Sc-PSMA-617 }\right.} \\
\text { almost identical } \\
\text { biodistribution data } \\
\text { compared to } \\
{\left[{ }^{177} \text { Lu]Lu-PSMA-617 }\right.}\end{array}$ & $\begin{array}{l}\text { (Umbricht et al. } \\
\text { 2017) }\end{array}$ \\
\hline & $\begin{array}{l}{ }^{43} \mathrm{SC}_{1}{ }^{47} \mathrm{SC} \\
{ }^{44} \mathrm{SC}\end{array}$ & $\begin{array}{l}\text { LNCaP cells } \\
+ \text { human }\end{array}$ & $\begin{array}{l}\text { BioD + PET + } \\
\text { SPECT }(2 \mathrm{~h} \\
\text { p.i. })\end{array}$ & $\begin{array}{l}\text { Tumor to liver ratio } \\
\text { between } 2.5 \text { and } 8.8 \text {. }\end{array}$ & $\begin{array}{l}\text { (Umbricht et al. } \\
\text { 2017; Eppard et al. } \\
\text { 2017) }\end{array}$ \\
\hline picagaDUPA & ${ }^{44} \mathrm{SC}$ & $\begin{array}{l}\text { PC3 cells, Male } \\
\text { NCr nude mice }\end{array}$ & $\begin{array}{l}\text { BioD + PET } \\
\text { (90 min p.i.) }\end{array}$ & $\begin{array}{l}\text { uptake } 13.8 \pm 0.6 \% \text { ID/ } \\
\text { g } \\
\text { enhanced binding } \\
\text { affinity to the target } \\
\text { for }\left[{ }^{44} \mathrm{Sc}\right] \mathrm{Sc}(\text { picaga)- } \\
\text { DUPA, and possibly } \\
\text { also from slower } \\
\text { blood clearance. }\end{array}$ & $\begin{array}{l}\text { (Vaughn et al. 2020a; } \\
\text { Vaughn et al. 2020b) }\end{array}$ \\
\hline $\begin{array}{l}\text { DOTA-RGD } \\
\text { NODAGA- }\end{array}$ & ${ }^{44} \mathrm{SC},{ }^{68} \mathrm{Ga}$ & $\begin{array}{l}\text { U87MG (human } \\
\text { glioblatoma) and }\end{array}$ & $\begin{array}{l}\mathrm{BioD}+\mathrm{PET} / \\
\mathrm{CT}\end{array}$ & $\begin{array}{l}{ }^{44} \text { SC stability using } \\
\text { NODA-functionalized }\end{array}$ & $\begin{array}{l}\text { (Domnanich et al. } \\
\text { 2017c; Hernandez }\end{array}$ \\
\hline
\end{tabular}


Table 6 Current state of pre-clinical studies performed on scandium radionuclides (Continued)

\begin{tabular}{|c|c|c|c|c|c|}
\hline $\begin{array}{l}\text { Type of } \\
\text { vector }\end{array}$ & $\begin{array}{l}\text { Radioisotope } \\
\text { used }\end{array}$ & $\begin{array}{l}\text { Tumor model or } \\
\text { human }\end{array}$ & $\begin{array}{l}\text { Bio- } \\
\text { Distributions } \\
\text { (BioD) } \\
\text { PET images }\end{array}$ & Main results & Reference \\
\hline $\begin{array}{l}\text { RGD } \\
\text { DOTA-NOC } \\
\text { NODAGA- } \\
\text { NOC }\end{array}$ & & $\begin{array}{l}\text { AR42J tumor- } \\
\text { bearing mice }\end{array}$ & $\begin{array}{l}\text { ( } 0.5 \text { to } 5 \mathrm{~h} \\
\text { p.i.) }\end{array}$ & $\begin{array}{l}\text { peptides was in- } \\
\text { creased compared to } \\
\text { the corresponding } \\
\text { radiolabeled one with } \\
{ }^{68} \mathrm{Ga}\end{array}$ & et al. 2014) \\
\hline $\begin{array}{l}\text { DOTA- } \\
\text { NAPamide }\end{array}$ & ${ }^{44} \mathrm{SC}_{1}{ }^{68} \mathrm{Ga}$ & $\begin{array}{l}\text { MC1-R positive } \\
\text { (B16-F10) and } \\
\text { negative (A375) } \\
\text { melanoma cell } \\
\text { lines. }\end{array}$ & $\begin{array}{l}\text { In cellulo, } \\
\text { BioD + PET/ } \\
\text { CT } \\
\text { (1 to } 4 \text { h p.i.) }\end{array}$ & $\begin{array}{l}\text { Uptake } 2.61 \pm 0.46 \% \\
\text { ID/g on B16-F10 and } \\
0.21 \pm 0.08 \% \text { ID/g on } \\
\text { A375 for }{ }^{44} S c-D O T A- \\
\text { NAPamide }\end{array}$ & (Nagy et al. 2017b) \\
\hline $\begin{array}{l}\text { CHX-A"- } \\
\text { DTPA-Fab } \\
\text { fragment of } \\
\text { Cetuximab }\end{array}$ & ${ }^{44} \mathrm{SC}$ & $\begin{array}{l}\text { U87MG (human } \\
\text { glioblastoma) in } \\
\text { tumor- bearing } \\
\text { mice) }\end{array}$ & $\begin{array}{l}\text { PET + BioD } \\
\text { (0.5 to } 6 \mathrm{~h} \\
\text { p.i.) }\end{array}$ & $\begin{array}{l}\text { rapid tumor uptake } \\
\text { (max. Uptake of } \sim 12 \% \\
\text { ID/g at } 4 \mathrm{~h} \text { p.i.) of } \\
\text { with excellent tumor- } \\
\text { to-background ratio }\end{array}$ & $\begin{array}{l}\text { (Chakravarty et al. } \\
\text { 2014) }\end{array}$ \\
\hline $\begin{array}{l}\text { DOTA- } \\
\text { Z }_{\text {HER2-2891 }}\end{array}$ & ${ }^{44} \mathrm{SC}$ & $\begin{array}{l}\text { HER2-SKOV3.ip } \\
\text { (human ovarian } \\
\text { cancer) in vitro } \\
\text { and in } \\
\text { xenografted mice }\end{array}$ & $\begin{array}{l}\text { BioD } \\
\text { (6 h p.i.) }\end{array}$ & $\begin{array}{l}\text { Higher tumor-to- } \\
\text { background contrast }\end{array}$ & (Honarvar et al. 2017) \\
\hline $\begin{array}{l}\text { DOTA- } \\
\text { antiCD20 }\end{array}$ & ${ }^{46} \mathrm{SC}$ & $\begin{array}{l}\text { Raji cells in wild } \\
\text { rats }\end{array}$ & $\begin{array}{l}\text { BioD } \\
\text { (72 h p.i.) }\end{array}$ & $\begin{array}{l}\text { similar biodistribution } \\
\text { pattern compared to } \\
\text { other radiolabeled } \\
\text { anti-CD20 } \\
\text { immunoconjugates }\end{array}$ & $\begin{array}{l}\text { (Moghaddam- } \\
\text { Banaem 2012) }\end{array}$ \\
\hline
\end{tabular}

nanomolar range, but in favor of ${ }^{\text {nat }}$ Ga-DOTATATE. The affinity to GRP (gastrin releasing peptide) receptors in the PC-3 cell line was higher for ${ }^{\text {nat }}$ Ga-DOTA$\mathrm{BN}[2-14] \mathrm{NH}_{2}$ than that of ${ }^{\text {nat }} \mathrm{Sc}-\mathrm{DOTA}-\mathrm{BN}[2-14] \mathrm{NH}_{2}\left(\mathrm{IC}_{50}(\mathrm{nM})\right.$ values $0.85 \pm 0.06$ vs. $6.49 \pm 0.13)$. Despite this difference, in another study both ${ }^{68} \mathrm{Ga}$ - and ${ }^{44} \mathrm{Sc}$-labeled DOTA-BN[2-14] $\mathrm{NH}_{2}$ showed comparable biodistribution and micro-PET imaging. (Koumarianou et al. 2012). Similar observations were reported by Ferguson et al. who compared $\left[{ }^{44 \mathrm{~g}} \mathrm{Sc}\right] \mathrm{Sc}$-DOTA-Ava-BBN, a bombesin receptor antagonist, to the $\left[{ }^{68} \mathrm{Ga}\right] \mathrm{Ga}-\mathrm{DOTA}-\mathrm{Ava}-\mathrm{BBN}$ in breast and prostate cancer model (Ferguson et al. 2020). In more recent studies, the binding affinity of ${ }^{\text {nat }}$ Sc-PSMA-617 was evaluated in comparison to ${ }^{\text {nat }}$ Ga-PSMA-617, however using different methods and cell lines (PC-3 PIP cells and PSMA+ LNCaP cells, respectively) (Umbricht et al. 2017; Eppard et al. 2017). Though, the binding affinity to the target was found to be in the same molar range. Both $\left[{ }^{44} \mathrm{Sc}\right] \mathrm{Sc}-$ and $\left[{ }^{68} \mathrm{Ga}\right] \mathrm{Ga}$-PSMA-617 exhibited similar in vivo behavior, with $\left[{ }^{44} \mathrm{Sc}\right] \mathrm{Sc}$-PSMA-617 displaying higher tumor-to-liver ratios at 15 and $30 \mathrm{~min}$ p.i. These values correlated more closely to $\left[{ }^{177} \mathrm{Lu}\right] \mathrm{Lu}-\mathrm{PSMA}-617$ than to $\left[{ }^{68} \mathrm{Ga}\right] \mathrm{Ga}-\mathrm{PSMA}-617$, and therefore were considered useful for pretherapeutic dosimetry (Umbricht et al. 2017).

The comparison of ${ }^{44} \mathrm{Sc}$ and ${ }^{68} \mathrm{Ga}$ for imaging of animals with melanocortin-1 receptor (MC1-R), positive tumors using DOTA-NAPamide, at $4 \mathrm{~h}$ p.i. revealed significantly higher tumor uptake of ${ }^{44} \mathrm{Sc}(81.7 \pm 7.7 \% \mathrm{ID} / \mathrm{g})$ over ${ }^{68} \mathrm{Ga}(17.3 \pm 1.85 \% \mathrm{ID} / \mathrm{g})$ (Nagy et al. 2017b). DOTA-puromycin was radiolabeled with the generator produced ${ }^{44} \mathrm{Sc}$ and investigated for the potential imaging of protein synthesis in vivo. In $\mu \mathrm{PET}$ images of tumor-bearing rats significant tumor uptake of $\left[{ }^{44} \mathrm{Sc}\right] \mathrm{Sc}$-DOTA-puromycin and a clear-cut tumor 
visualization were demonstrated. In addition, the cellular uptake of $\left[{ }^{44} \mathrm{Sc}\right] \mathrm{Sc}$-DOTA-puromycin could be suppressed by blocking protein synthesis (Eigner et al. 2013).

In vitro, $\left[{ }^{47} \mathrm{Sc}\right] \mathrm{Sc}$-folate demonstrated effective reduction of folate receptorpositive ovarian tumor cell viability similar to ${ }^{177} \mathrm{Lu}$-folate, but ${ }^{90} \mathrm{Y}$-folate was more potent at equal activities due to the higher energy of emitted $\beta^{-}$-particles. Comparable tumor growth inhibition was observed in mice that obtained the same estimated absorbed tumor dose $(\sim 21 \mathrm{~Gy})$ when treated with $\left[{ }^{47} \mathrm{Sc}\right] \mathrm{Sc}$-folate $(12.5 \mathrm{MBq}), \quad\left[{ }^{177} \mathrm{Lu}\right] \mathrm{Lu}$-folate $(10 \mathrm{MBq})$, and $\left[{ }^{90} \mathrm{Y}\right] \mathrm{Y}$-folate $(5 \mathrm{MBq})$, respectively. However, there were no statistically significant differences among the therapeutic effects observed in treated groups (Siwowska et al. 2019).

CHX-A"-DTPA has been successfully used for radiolabeling of the monoclonal antibody (mAb) Cetuximab. (Chakravarty et al. 2014) Another study evaluated DOTA-HPMA (N-(2-hydroxypropyl)methacrylamide) conjugates for labeling efficiency with ${ }^{68} \mathrm{Ga},{ }^{177} \mathrm{Lu}$ and ${ }^{44} \mathrm{Sc}$ and showed that the ${ }^{44} \mathrm{Sc}$ labeled polymer allowed for in vivo PET imaging and ex vivo measurements of organ distribution for up to 24 h (Eppard et al. 2018).

\section{Clinical experiences}

The validity, usefulness and advantages of ${ }^{44} \mathrm{Sc}$ have been demonstrated by studies featuring ${ }^{44} \mathrm{Sc}$-radiolabeled targeting vectors, including ${ }^{44} \mathrm{Sc}$ radiopharmaceuticals in early clinical studies. The first of them has been performed using $\left[{ }^{44} \mathrm{Sc}\right] \mathrm{Sc}$-DOTATOC prepared from ${ }^{44}$ Sc produced in a cyclotron (Singh et al. 2017). Two patients were included in this study after being treated by peptide receptor radionuclide therapy due to neuroendocrine neoplasms. The obtained image quality was comparable to that of ${ }^{68} \mathrm{Ga}$. This very encouraging proof-of-concept study showed no clinical adverse effects with normal hematology, nor with renal and hepatic profiles.

The other studies were conducted in patients with metastasized castrate-resistant prostate cancer (Eppard et al. 2017; Khawar et al. 2018a; Khawar et al. 2018b). A firstin-human investigation was carried out in a cohort of four patients (mean age $70.0 \pm$ 1.8 years) registered for $\left[{ }^{177} \mathrm{Lu}\right] \mathrm{Lu}-\mathrm{PSMA}-617$ therapy. Physiological tracer uptake was observed in kidneys, liver, spleen, small intestine, urinary bladder, and salivary glands and pathological uptake in both soft and skeletal metastases. SUV values were significantly lower in the kidneys (14.0) compared to $\left[{ }^{68} \mathrm{Ga}\right] \mathrm{Ga}-\mathrm{PSMA}-11$ PET (30.5). All other measured SUV values did not show a statistically significant difference. Tumorto-liver ratios were found to lie between 1.9 and 8.3 for $\left[{ }^{68} \mathrm{Ga}\right] \mathrm{Ga}-\mathrm{PSMA}-11$ and between 2.5 and 8.8 for $\left[{ }^{44} \mathrm{Sc}\right]$ Sc-PSMA-617 after $120 \mathrm{~min}$. For $\left[{ }^{44} \mathrm{Sc}\right] \mathrm{Sc}$-PSMA-617 the ratios were higher and no statistically significant differences were observed. Total and $\%$ activity were highest in the liver followed by kidneys, spleen, small intestine and salivary glands. Rapid wash-out was seen in liver and spleen, and gradually over time in kidneys. Kidneys received the highest radiation absorbed dose of 0.354 (0.1800.488) $\mathrm{mSv} / \mathrm{MBq}$. No adverse pharmacological effects were observed. Still, the authors concluded that the clinical advantages for individual dosimetry or other applications like intraoperative applications need to be investigated in further studies (Eppard et al. 2017). 
The impact of physical properties of ${ }^{44 \mathrm{~g}} \mathrm{Sc}$ on image quality has been studied by Bunka et al. (Bunka et al. 2016) and recently evaluated by Rosar et al. (Rosar et al. 2020) in comparison to ${ }^{68} \mathrm{Ga}$ with different imaging phantoms. The lower mean positron energy of ${ }^{44 \mathrm{~g}} \mathrm{Sc}(0.63 \mathrm{MeV})$ compared to ${ }^{68} \mathrm{Ga}(0.83 \mathrm{MeV})$ can result in better spatial image resolutions. However, high-energy $\gamma$-rays $(1157 \mathrm{keV})$ are emitted at high rates $(99.9 \%)$ during ${ }^{44 g} \mathrm{Sc}$ decay, which can reduce image quality. Despite the presence of high-energy $\gamma$-rays in ${ }^{44 g} \mathrm{Sc}$ decay, a higher image resolution of small structures was observed with ${ }^{44 \mathrm{~g}} \mathrm{Sc}$ when compared to ${ }^{68} \mathrm{Ga}$. Structures as small as $1 \mathrm{~mm}$ could be visualized and analyzed using two different pre-clinical PET scanners. Recently, Lima et al. (Lima et al. 2020) evaluated quantitative capabilities of ${ }^{44}$ Sc-PET using a commercial PET scanner and concluded that that clinical ${ }^{44} \mathrm{Sc}$-PET imaging has the potential to provide signal recovery in lesions of different sizes comparable to current ${ }^{18} \mathrm{~F}$-PET standards.

Biodistribution and radiation exposure to normal organs with $\left[{ }^{44} \mathrm{Sc}\right] \mathrm{Sc}-\mathrm{PSMA}-617$ in metastatic castration-resistant prostate carcinoma patients were investigated by Khawar et al. (Khawar et al. 2018a). These authors extrapolated the pharmacokinetics of $\left[{ }^{44} \mathrm{Sc}\right]$ Sc-PSMA-617 to that of $\left[{ }^{177} \mathrm{Lu}\right]$ Lu-PSMA-617 and demonstrated that pharmacokinetics of $\left[{ }^{44} \mathrm{Sc}\right] \mathrm{Sc}$-PSMA-617 PET/CT imaging could be utilized with the intent of predicting normal organ-absorbed doses and maximum permissible activity in patients scheduled for therapy with $\left[{ }^{177} \mathrm{Lu}\right] \mathrm{Lu}-\mathrm{PSMA}-617$. Physiological tracer uptake was seen in kidneys, liver, spleen, small intestine, urinary bladder, and salivary glands and metastases. Kidneys, with the highest radiation absorbed dose of $0.319 \mathrm{mSv} / \mathrm{MBqm}$ were the critical organs, followed by the urinary bladder wall, spleen, salivary glands, and liver. Red marrow dose was found to be $0.0331 \mathrm{mSv} / \mathrm{MBq}$. The mean effective dose of $0.0389 \mathrm{mSv} / \mathrm{MBq}$ and effective dose of $1.95 \mathrm{mSv}$ was estimated from $50 \mathrm{MBq}$ (treatment planning dose) of $\left[{ }^{44} \mathrm{Sc}\right]$ Sc-PSMA-617 (Khawar et al. 2018a). These first clinical studies using $\left[{ }^{44} \mathrm{Sc}\right]$ Sc-DOTA-TOC and $\left[{ }^{44} \mathrm{Sc}\right]$ Sc-PSMA-617 confirmed the potential of ${ }^{44} \mathrm{Sc}$-labeled tracers as promising radiopharmaceuticals, their use is especially relevant in pretherapeutic dosimetry (Kostelnik and Orvig 2019).

To date, very limited data is available on radiation doses from ${ }^{47} \mathrm{Sc}$ labelled radiopharmaceuticals. The absorbed dose in human organs of ${ }^{47}$ Sc-EDTMP (ethylene-diamine-tetramethylene-phosphonic acid) has been extrapolated from animal biodistribution using the MIRDOSE formalism. However the animal biodistribution data in this study were collected using EDTMP radiolabeled with the reactor produced ${ }^{46} \mathrm{Sc}$ of rather low specific activity $148 \mathrm{MBq} / \mathrm{mg}$ (Deilami-Nezhad et al. 2017). The radionuclide ${ }^{47} \mathrm{Sc}$ is a low energy beta emitter, similarly to ${ }^{177} \mathrm{Lu}$, and the mean range of its radiation in bone is $0.20 \mathrm{~mm}$, compared to $0.15 \mathrm{~mm}$ for ${ }^{177} \mathrm{Lu}$ (as extrapolated from Bouchet et al. (Bouchet et al. 2000)).

\section{Quality specifications}

The chemically identical radiopharmaceuticals for diagnosis and therapy using the matched pair ${ }^{43} \mathrm{Sc}$ or ${ }^{44} \mathrm{Sc}$ with ${ }^{47} \mathrm{Sc}$ are very appealing. Although several groups are now producing scandium radionuclides locally and a few centers demonstrated the potential of Sc radionuclides for medical applications, the benefit of their use in the clinical setting is yet to be shown. Given the amount of work and documentation needed 
to obtain the approval for a clinical trial of a new radiopharmaceutical, this review aims to present the production options for Sc radionuclides and related quality constraints. This information might be useful when implementing Sc radionuclides production technology in the existing or planned production facilities.

${ }^{43} \mathrm{Sc}\left(\beta^{+}=88.1 \%, \mathrm{E}_{\beta+}=476 \mathrm{keV}\right)$ and ${ }^{44 \mathrm{~g}} \mathrm{Sc}\left(\beta^{+}=94.3 \%, \mathrm{E}_{\beta_{+}}=632 \mathrm{keV}\right)$ have half-lives of $3.89 \mathrm{~h}$ and $3.97 \mathrm{~h}$, respectively (Singh and Chen 2015). Although properties of these two isotopes are very similar, the main difference is the high-energy $\gamma$-radiation $(\mathrm{E} \gamma=$ $1157 \mathrm{keV} ; \mathrm{I} \gamma=100 \%$ ) associated with ${ }^{44 \mathrm{~g}} \mathrm{Sc}$. The high energy gamma radiation, similarly to that of ${ }^{89} \mathrm{Zr}(\mathrm{E} \gamma 909 \mathrm{keV}$; I $\gamma=99 \%)$, may not hamper its clinical use. It is considerd advantageous for ${ }^{44 \mathrm{~g}} \mathrm{Sc}$ as the radionuclide of choice for $3-\gamma$ photons imaging, a new modality of imaging (Sitarz 2020). Additionally, ${ }^{44 \mathrm{~m}} \mathrm{Sc}$, which is co-produced with ${ }^{44 \mathrm{~g}} \mathrm{Sc}$, has a half-life of $58.6 \mathrm{~h}$ and has been suggested for use as an in vivo PET generator for ${ }^{44 \mathrm{~g}} \mathrm{Sc}$ (Alliot et al. 2015a). However, the longer half-life coupled with the high-energy $\gamma$ ray emitted from ${ }^{44 \mathrm{~S}} \mathrm{Sc}$ may lead to the unfavorable dosimetry for shorter biodistribution studies (Alliot et al., 2015a).

High radionuclidic purity ${ }^{44 \mathrm{~S}} \mathrm{Sc}$ production with proton irradiation necessitates the use of enriched target material and a recycling procedure to keep the cost reasonable. The determination of acceptable limits for each radionuclidic impurity requires careful consideration, as it can have an adverse effect on the implementation of new production methods. Potential contamination with ${ }^{43} \mathrm{Sc}$ can be argued to have no impact on patient safety and quality of images since it is a positron emitter with no high energy gamma radiation component, in contrast to the expected radiation burden due to ${ }^{44 g} \mathrm{Sc}$ contamination in ${ }^{43} \mathrm{Sc} .{ }^{44 \mathrm{~m}} \mathrm{Sc}$ decays to ${ }^{44} \mathrm{Sc}$ with low energy gamma $(271 \mathrm{keV})$ emission, which does not cause any harm to the patient. The limit for ${ }^{44 \mathrm{~m}} \mathrm{Sc}$ content should be determined to avoid unnecessary radiation doses to the patient, because of the longer effective half-life of the ${ }^{44 \mathrm{~m}} \mathrm{Sc} /{ }^{44} \mathrm{Sc}$ isotope pair. However, the biological half-life and critical organs should be determined for unchelated scandium isotopes before using worst-case dosimetry calculations for the determination of the limit of longer half-life impurities, as discussed earlier for ${ }^{68} \mathrm{Ga}$ labelled peptides and influence of ${ }^{68} \mathrm{Ge}$ breakthrough on dosimetry (Velikyan et al. 2013).

From that perspective, ${ }^{43} \mathrm{Sc}$ has the most favorable radiation characteristics for conventional PET, however it can be produced efficiently only using alpha particle beams. ${ }^{44} \mathrm{Sc}$ is in the most advanced state and has the highest potential for broad applications. Medical cyclotrons that currently supply ${ }^{18} \mathrm{~F}$ to hospitals can be used to produce ${ }^{44 \mathrm{~g}} \mathrm{Sc}$ or ${ }^{43} \mathrm{Sc}$, with a solid target system. The use of liquid target might not be reasonable as the amount of enriched material nedded is high. With the near to $4 \mathrm{~h}$ half-life and reasonable production cross-section, there is a potential for regional distribution following mass production at a single cyclotron unit with solid target. With the increasing numbers of installed cyclotrons, the availability of ${ }^{43 / 44} \mathrm{Sc}$ may increase. Aiming for the production of high activities, a solid target is needed. This requires the addition of specialized hardware on the cyclotron and in the processing hot-cell, which is available from cyclotron providers but not frequently installed on ${ }^{18} \mathrm{~F}$ production machines. The co-emission of a high-energy $\gamma$-ray similar to ${ }^{89} \mathrm{Zr}$ has to be taken into consideration when planning for radiation protection. If not controlled, it may increase the radiation dose to the patient and staff. ${ }^{44} \mathrm{Ti} /{ }^{44} \mathrm{Sc}$ generator currently has a high production cost and requires a regular and efficient use of the generator over long periods. ${ }^{44 \mathrm{~m}} \mathrm{Sc}$ half- 
life enables transportation of ${ }^{44 \mathrm{~m}} \mathrm{Sc}$-labeled radiopharmaceuticals to hospitals that are located quite far away from the radiopharmaceutical production site (centralized production). This is based on the in-vivo generator principle.

Both positron emitters, ${ }^{43} \mathrm{Sc}$ and ${ }^{44 g} \mathrm{Sc}$ can be used for theranostic studies with ${ }^{177} \mathrm{Lu}$ or other lanthanides. Scandium has chemistry close to ${ }^{177} \mathrm{Lu}$ and possibility of centralized production at the regional level, which makes it more desirable than ${ }^{68} \mathrm{Ga}$ (local production only) for its use in a theranostic pair. Application of ${ }^{47} \mathrm{Sc}$, as an alternative radionuclide to ${ }^{177} \mathrm{Lu}$, was proposed in earlier works (Srivastava 2013). The advantage of ${ }^{47} \mathrm{Sc}$ production compared to that of n.c.a. ${ }^{177} \mathrm{Lu}$, is the relatively easy isolation of the radionuclide from the target, but the disadvantage is the smaller cross-section of the nuclear reaction compared to ${ }^{177} \mathrm{Lu}$ production. Nonetheless, the main concern lies with the co-produced impurities. Another limitation concerns the availability of the starting enriched material needed for the set-up of efficient separation chemistry. At the time of writing this article, we are aware of several research groups developing ways of overcoming these limitations, as presented by Jalilian et al. (Jalilian et al. 2020).

When it comes to the scandium-based radiopharmaceuticals, unlike with ${ }^{68} \mathrm{Ga}$, the scientific community involved is unfortunately far from following a standardized procedure. From Table 5, it is inferred that neither the metallic impurity contents nor the radionuclidic purity of the resulting radiolabeled compound is always given. There is also a lack of homogeneity in the expression of the molar activity of the resulting radiolabeled vector. Though, some compromise could be found on the radiolabeling proto$\mathrm{col}$ and quality control. This is certainly a good basis to pave the way for a monograph for the European Pharmacopeia, together with the use of the recently approved nomenclature guidelines for radiopharmaceuticals (Coenen et al. 2017).

Next to the radionuclide generators and kits, the European Union (EU) directive 2001/83 (The European Parliament and the Council of European Union 2001) dealing with radiopharmaceuticals, defines also the "radionuclide precursors" (EU Commission 2004). The radionuclide precursor is defined as "any other radionuclide produced for the radio-labeling of another substance prior to administration" and as such has to hold a marketing authorization when introduced to the market. Even if used in a hospital radiopharmacy with a cyclotron on-site, and having a status of starting material, as postulated in a position paper by Neels et al. (Neels et al. 2019), the radionuclide precursor needs to be controlled by performing several quality control tests (identity, purity, assay, etc.). To assure safe use in humans, these tests and limits should comply with certain quality standards, and be supported by a suitable quality management system. It is generally accepted that such quality standards are established in Pharmacopoeia monographs.

The expected final form of the radionuclide, regardless of the production method used, is the form of solution for radiolabeling. The Ph.Eur. General monograph on Radiopharmaceutical preparations (0125) can serve as the reference for establishing quality specifications for the final product solution of ${ }^{43} \mathrm{Sc},{ }^{44} \mathrm{Sc}$ or ${ }^{47} \mathrm{Sc}$ (EDQM 2020a). One should bear in mind that the Ph.Eur. monographs on Lutetium $\left({ }^{177} \mathrm{Lu}\right)$ solution for radiolabelling (mon. 2798) (EDQM 2020b), and Yttrium $\left({ }^{90} \mathrm{Y}\right.$ ) chloride solution for radiolabelling (mon. 2803) (EDQM 2020c), can be also very informative, similarly as the monograph of Gallium-68 ( ${ }^{68} \mathrm{Ga}$ ) chloride solution for radiolabelling (mon. 2464) (EDQM 2020d). 
One needs to remember, however, that the specified parameters will depend on the production route (target material, nuclear reaction, accompanying nuclear reactions, chemical processing etc.). For example, when using ${ }^{44} \mathrm{Sc}$ obtained from the ${ }^{44} \mathrm{Ti} /{ }^{44} \mathrm{Sc}$ radionuclide generator, the potential breakthrough of ${ }^{44} \mathrm{Ti}$ will be of concern as well as its impact on the quality (and safety) of the final radiopharmaceutical. The detailed specifications for quality control of generator eluate as well as for the quality assessement of ${ }^{44} \mathrm{Sc}$ radiolabeled PSMA-617 prior to its administration to patients were developed by Eppard (Eppard 2018).

The Group 14 (radioactive compounds) of European Pharmacopoeia elaborated the Guide for the elaboration of monographs on radiopharmaceutical preparations, European Pharmacopoeia, EDQM Edition 2018, which should help to prepare the monographs for new radiopharmaceuticals (https://www.edqm.eu/sites/default/files/ guide_-_guide_for_the_elaboration_of_monographs_on_radio-pharmaceutical_ preparations_-_october_2018.pdf). Based on this Ph. Eur. Guide, exemplary general list of tested parameters and the involved methods for the potential scandium radionuclide precursors are briefly discussed below.

\section{Title, definition and production sections}

In general, the definition states that the monograph applies to the substance obtained by a certain route of production and in the case of a radionuclide precursor the name of the substance is completed by "for radiolabeling". Therefore, in case of the new monographs, e.g. for gallium-68 and technetium- $99 \mathrm{~m}$, the title of the monograph itself contains a reference to the production method, like: Gallium $\left({ }^{68} \mathrm{Ga}\right.$ ) Chloride (Accelerator-Produced) Solution For Radiolabelling (mon. 3109) (EDQM 2020e) or Sodium Pertechnetate ${ }^{99 m}$ Tc) Injection (Accelerator-Produced (mon. 2891) (EDQM 2020f).

Such titles and definitions are intended to make the recipient/reader aware that other methods of obtaining radionuclides may and, in fact do, result in a completely different profile of potential contaminants, mainly radionuclidic. These constraints apply to the radionuclides of scandium, therefore it is not possible to develop a single monograph even for one of the scandium radionuclides, but it would be necessary to develop several monographs for this radionuclide depending on the way the radionuclide is produced. In the following, a monograph-like characteristics are proposed.

\section{Characters}

Appearance: clear, colourless solution.

Half-life and nature of radiation of scandium radionuclides:

Scandium-47: $\mathrm{T}_{1 / 2}=3.35 \mathrm{~d}, \mathrm{E} \beta^{-} \mathrm{av}=162 \mathrm{keV}, \mathrm{E} \gamma=0.159 \mathrm{MeV}$.

Scandium-43: $\mathrm{T}_{1 / 2}=3.89 \mathrm{~h}, 88 \% \mathrm{E} \beta^{+}, \mathrm{E} \beta^{+}$av. $=476 \mathrm{keV}, \mathrm{E} \gamma=0.373 \mathrm{MeV}(23 \%)$.

Scandium-44: $\mathrm{T}_{1 / 2}=4.04 \mathrm{~h}, 94.27 \% \mathrm{E} \beta^{+} \_$and $5.73 \% \mathrm{EC}, \mathrm{E} \beta^{+} \mathrm{av} .=632 \mathrm{keV}, \mathrm{E} \gamma=1.157$ $\mathrm{MeV}$ (99.9\%).

Identification: (characteristic of type of radiation - spectra, approximate half-life, $\mathrm{pH}$, chromatography)

Gamma-ray spectrometry.

The most prominent gamma photon of scandium- 47 has an energy of $0.159 \mathrm{MeV}$. 
The most prominent gamma photon of scandium-43 has an energy of $0.373 \mathrm{MeV}$.

The most prominent gamma photon of scandium-44 has an energy of $1.157 \mathrm{MeV}$. $\mathrm{pH}$ : 1.0 to 2.0 , using a $\mathrm{pH}$ indicator strip $\mathrm{R}$.

Tests

Radionuclidic purity For ${ }^{90} \mathrm{Y},{ }^{177} \mathrm{Lu}$ and ${ }^{68} \mathrm{Ga}$ (generator produced) the Ph.Eur. recommended limit is minimum of $99.9 \%$ of the total radioactivity, however, for the accelerator-produced ${ }^{68} \mathrm{Ga}$ (draft monograph 3109 published in Pharmeuropa 30.4) the radionuclidic purity limit is only $98 \%$ due to the expected and the inevitable presence of contaminants such as ${ }^{66} \mathrm{Ga}$ and ${ }^{67} \mathrm{Ga}$.

The expected radionuclide contaminants in ${ }^{47} \mathrm{Sc}$ radionuclide precursor are ${ }^{46} \mathrm{Sc}$ $\left(\mathrm{T}_{1 / 2}=83.8 \mathrm{~d}\right)$ and ${ }^{48} \mathrm{Sc}\left(\mathrm{T}_{1 / 2}=43.7 \mathrm{~h}\right)$. Although their presence has been reported, the limits for individual radionuclidic impurities were not yet determined.

In case of ${ }^{43} \mathrm{Sc}$, irradiation of ${ }^{46} \mathrm{Ti}$ targets $(97.0 \%$ enriched) with protons yielded a product of high radionuclidic purity, containing $98.2 \%{ }^{43} \mathrm{Sc}$ and only $1.5 \%{ }^{44} \mathrm{Sc}$. Longterm $\gamma$-spectroscopy measurements determined low activity levels of $0.079 \%{ }^{44 \mathrm{~m}} \mathrm{Sc}$, ${ }^{46} \mathrm{Sc},{ }^{47} \mathrm{Sc},{ }^{48} \mathrm{Sc}$ and $0.34 \%{ }^{44 \mathrm{~m}} \mathrm{Sc},{ }^{47} \mathrm{Sc},{ }^{48} \mathrm{Sc}$ in the final products of irradiated ${ }^{46} \mathrm{Ti}$ and ${ }^{43} \mathrm{Ca}$ targets, respectively. (Domnanich et al. 2017b).

Chemical purity The ions of copper, iron, zinc and lead and the traces of target material such as $\mathrm{Ca}$ or $\mathrm{Ti}$.

Since DOTA is the most common chelator used for labeling with ${ }^{47} \mathrm{Sc}$, it can be assumed that the content of chemical impurities such as copper, iron, zinc and lead ions may have an impact on ${ }^{47} \mathrm{Sc}$ quality. The content of chemical impurities may vary depending on the processing method and purity of reagents. The methods used for determination of chemical contaminants included: determination of $\mathrm{Ti}$ using ICP-MS or determination of metallic impurities by ICP atomic emission spectrometry. These instrumental techniques can be recommended to establish chemical impurity acceptance levels.

Although the influence of metallic impurities on the labelling yields of DOTAchelated peptides has been studied in detail, the first report dealing with Sc labelled DOTATATE is just recently published by Walczak et al. (Walczak et al. 2019).

Radiochemical purity In case of ${ }^{68} \mathrm{Ga}$ and ${ }^{111} \mathrm{In}$, the Ph.Eur. monographs for diagnostic radionuclide precursors $(2464,1227)$ require the presence of gallium or indium min. $95 \%$ in +3 ion form, whereas for therapeutic radionuclides like ${ }^{177} \mathrm{Lu}$ (mon. 2798) and ${ }^{90} \mathrm{Y}$ (mon. 2803) the limit is increased to $\min .99 \%$ in +3 ion form. It seems that these rules should be also adopted in case of ${ }^{43} \mathrm{Sc}$ and ${ }^{44} \mathrm{Sc}$ radionuclide precursors and ${ }^{47} \mathrm{Sc}$, respectively.

In the Ph.Eur. monographs for ${ }^{177} \mathrm{Lu}$ and ${ }^{90} \mathrm{Y}$ solutions for radiolabeling, for the assessment of radiochemical purity, in addition to the chemical determination of the radiometal form as trivalent cation, the TLC system recommends using complexes of these radiometals with pentetic acid as reference. 
To test the radiochemical purity of obtained ${ }^{47} \mathrm{Sc}$ when used for radiolabeling of selected common chelators such as DOTA, DTPA or EGTA, or peptide conjugates such as DOTATATE or DOTA-bombesin, with further TLC development to assess the radiochemical purity of ${ }^{47} \mathrm{Sc}$-labelled compound. Usually, the radiochemical purity should be not less than $98-99 \%$ to confirm the quality of ${ }^{47} \mathrm{Sc}$.

This approach can also serve as the indirect test of ${ }^{47} \mathrm{Sc}$ suitability for radiolabeling, and the experiments can be designed to check the effective specific activity of obtained ${ }^{47} \mathrm{Sc}$ solutions. Such tests provide very useful information during the process development, especially when instrumental methods for determination of chemical purity are not available on-site.

Bacterial endotoxins General applicable limit for the presence of bacterial endotoxins in radiopharmaceutical preparations is less than $175 \mathrm{IU} / \mathrm{V}$, V being the maximum volume to be used for the preparation of a single patient dose, if intended for use in the manufacture of parenteral preparations without a further appropriate procedure for the removal of bacterial endotoxins. Whereas, however, it should be borne in mind that the limit of $175 \mathrm{IU} / \mathrm{V}$ applies to the final injection preparation, therefore the determination of the limit of bacterial endotoxins for the radionuclide precursor should take into account the additional effect of the labelled substance and should therefore be established on the basis of actual results obtained for several batches of the radionuclide precursor intended for radiolabeling.

Sterility The test applies if intended for use in the manufacture of parenteral preparations without a further appropriate sterilization procedure.

From the regulatory point of view, labeling efficiency of ligands is usually tested at different $\mathrm{pH}$, temperature and ligand concentrations (or more precisely, at different radiometal-to-ligand molar ratios), and monitored as a function of time to optimize the radiolabeling.

The preparation of ${ }^{43 / 44 / 47}$ Sc-radiolabeled peptides for patient administration is designed to be performed on a modular system in which the final radiotracer is typically purified on a cartridge and diluted in a physiological vehicle before injection. Using the same commercially-available modular entity as is commonly used for the preparation of ${ }^{68} \mathrm{Ga}$-radiopharmaceuticals has the advantage to allow the preparation of ${ }^{43 / 44 / 47} \mathrm{Sc}$ radiopharmaceuticals for clinics without further evaluation and GMP validation of the system.

All these elements combined with a larger availability of the isotope production sites and broader distribution network are expected to allow more clinical trials with scandium radionuclides labelled radiopharmaceuticals (Domnanich et al. 2017c). These radionuclides have attracted considerable interest in the last decade and their broader availability opens new avenues for investigations.

\section{Conclusions}

The ${ }^{44} \mathrm{Sc} /{ }^{47} \mathrm{Sc}$ or ${ }^{43} \mathrm{Sc} /{ }^{47} \mathrm{Sc}$ pairs are appealing true theranostic radionuclides for Nuclear Medicine. Reliable methodologies for the production of all discussed herein medical scandium radionuclides exist and are increasingly reliable. With the increasing 
availability of scandium PET isotopes, some preclinical studies have been conducted, but remain limited and mostly performed with peptides. Since scandium exhibits suitable conjugation chemistry to be coupled with MAbs, and ${ }^{44 \mathrm{~m}} \mathrm{Sc}$ half life is adapted to long biodistribution time, it paves the way for bringing new developments in this area. Scandium-based vectors from diagnosis to therapy offer a great opportunity for dosimetric calculations and the development of personalized medicine.

Among scandium radionuclides, the ${ }^{44} \mathrm{Sc}$ seems to be in the most advanced state. Several production and purification methods were developed and some hold the promise of their relatively easy adaptation to the locally available infrastructure. At present, the primary importance of ${ }^{44} \mathrm{Sc}$ lies in its potential broad-scale availability based on the production in medical cyclotrons and the possibility to use it as the diagnostic match with ${ }^{177} \mathrm{Lu}$ or ${ }^{47} \mathrm{Sc}$. However, efficient production of ${ }^{47} \mathrm{Sc}$ is still not developed though the half life of ${ }^{47} \mathrm{Sc}$ allows its production in a centralized facility, which might provide this radionuclide to several countries. Its widespread use will be questionable if one considers the current availability of ${ }^{177} \mathrm{Lu}$ and the problems associated with the use of a therapeutic agent without centralised marketing authorisation. The shorter half-life of ${ }^{44} \mathrm{Sc}$ can be beneficial considering the lower radiation dose for the patients. The main issue is the co production of ${ }^{46} \mathrm{Sc}$ when Ti target is used, but that is not a problem when produced through $\mathrm{Ca}$ target.

The ${ }^{44} \mathrm{Sc}$ is an alternative to ${ }^{68} \mathrm{Ga}$, a well-established radiometal, with a similar field of application. The availability of ${ }^{68} \mathrm{Ga}$ from generator gave a boost of its widespread use, but it is clear now, that after the initial success in the introduction of new diagnostics (somatostatin analogues and PSMA), production capacity and cost efficiency will be the main factors determining the future of these examinations, and the interest of centralized production. Additionally, the short half-life of ${ }^{68} \mathrm{Ga}$ may limit its use for some pharmakokinetics studies. These factors favor fluorine labeling over radiometals. ${ }^{44} \mathrm{Sc}$ can find its place in the palette of medical cyclotrons, which could be capable of producing scandium before the daily ${ }^{18} \mathrm{~F}$ irradiation. Using the $\left[{ }^{18} \mathrm{~F}\right] \mathrm{FDG}$ transportation channels for shipping ${ }^{44} \mathrm{Sc}$ solution for radiolabeling or the GMP produced ${ }^{44} \mathrm{Sc}$ tracers to the nuclear medicine departments facilitates the use of new specialized tracers, currently relying on the ${ }^{68} \mathrm{Ge} /{ }^{68} \mathrm{Ga}$ generator supply.

The authors trust that the medical applications of scandium radionuclides will be growing, however standardization of their quality is still needed. The question remains whether there is enough experience already to draft the pharmacopoeia monograph for any of scandium radionuclides as radipharmaceutical precursors and which of the scandium radionuclides becomes economically feasible.

Acknowledgements

Not applicable.

Authors' contributions

Conceptualization, RM, SHM; methodology, RM, SHM; validation, SHM, CA, FH, PG; writing-original draft preparation, RM, SHM, CA, FH, DS, VF, PG, ...; writing-review and editing, RM, SHM, FH, PG.; funding acquisition, RM., SHM, FH. PG. All authors read and approved the final manuscript.

Funding

This work was partly supported by the IAEA/CRP code F22053 and the Polish Ministry of Science and Higher Education, Grant No. 3639/FAO/IAEA/16/2017/0 and the CERAD project, financed under Smart Growth Operational Programme 2014-2020, Priority IV, Measure 4.2. POIR.04.02.00-14-A001/16. This work was also supported by grants from the French National Agency for Research called "Investissements d'Avenir", Equipex Arronax-Plus (ANR-11-EQPX0004), Labex IRON (ANR-11-LABX-18-01) and ISITE NEXT (ANR-16-IDEX-0007). 
Availability of data and materials

Data sharing is not applicable to this article as no datasets were generated or analysed during the current study.

\title{
Declarations
}

Ethics approval and consent to participate

Not applicable.

\section{Consent for publication}

Not applicable.

\section{Competing interests}

The authors declare that they have no competing interests.

\begin{abstract}
Author details
${ }^{1}$ Radioisotope Centre POLATOM, National Centre for Nuclear Research, Andrzej Soltan 7, 05-400 Otwock, Poland. 2Laboratoire Subatech, UMR 6457, IMT Nantes Atlantique /CNRS-IN2P3 / Université de Nantes, 4 Rue A. Kastler, BP 20722, 44307 Nantes Cedex 3, France. ${ }^{3}$ ARRONAX GIP, 1 rue Aronnax, 44817 Nantes Cedex, France. ${ }^{4}$ CRCINA, Inserm / CNRS / Université de Nantes, 8 quai Moncousu, 44007 Nantes Cedex 1, France. ${ }^{5}$ Faculty of Medicine, Department of Medical Imaging, Division of Nuclear Medicine and Translational Imaging, University of Debrecen, Nagyerdei krt. 98, Debrecen 4032, Hungary. ${ }^{6}$ Scanomed Ltd., Nagyerdei krt. 98, Debrecen 4032, Hungary.
\end{abstract}

Received: 3 February 2021 Accepted: 26 March 2021

Published online: 25 May 2021

\section{References}

Alliot C, Audouin N, Barbet J, Bonraisin AC, Bosse V, Bourdeau C, et al. Is there an interest to use deuteron beams to produce non-conventional radionuclides? Front Med. 2015b;2:31. https://doi.org/10.3389/fmed.2015.00031.

Alliot C, Kerdjoudj R, Michel N, Haddad F, Huclier-Markai S. Cyclotron production of high purity (44m,44)Sc with deuterons from (44)CaCO3 targets. Nucl Med Biol. 2015a;42(6):524-9. https://doi.org/10.1016/j.nucmedbio.2015.03.002.

Bartoś B, Majkowska A, Krajewski S, Bilewicz A. New separation method of no-carrier-added47Sc from titanium targets. Radiochim Acta. 2012;100(7):457-62. https://doi.org/10.1524/ract.2012.1938.

Bokhari TH, Mushtaq A, Khan IU. Separation of no-carrier-added radioactive scandium from neutron irradiated titanium. J Radioanal Nucl Chem. 2009;283(2):389-93.

Bouchet LG, Bolch WE, Goddu SM, Howell RW, Rao DV. Considerations in the selection of radiopharmaceuticals for palliation of bone pain from metastatic osseous lesions. J Nucl Med. 2000;41(4):682-7.

Bunka M, Muller C, Vermeulen C, Haller S, Turler A, Schibli R, et al. Imaging quality of (44)SC in comparison with five other PET radionuclides using Derenzo phantoms and preclinical PET. Appl Radiat Isot. 2016;110:129-33. https://doi.org/10.1016/j.a pradiso.2016.01.006.

Braccini S. Compact medical cyclotrons and their use for radioisotope production and multi-disciplinary research: Proc Cyclotrons, TUD01. https://www.accelconfwebcernch/AccelConf/cyclotrons2016/papers/tud01.pdf; 2016. p. 229-34.

Carzaniga TS, Braccini S. Cross-section measurement of (44m)Sc,(47)Sc, (48)Sc and (47)Ca for an optimized (47)Sc production with an 18MeV medical PET cyclotron. Appl Radiat Isot. 2019;143:18-23. https://doi.org/10.1016/j.apradiso.2018.10.015.

Carzaniga TS, van der Meulen NP, Hasler R, Kottler C, Peier P, Turler A, et al. Measurement of the (43)Sc production crosssection with a deuteron beam. Appl Radiat Isot. 2019;145:205-8. https://doi.org/10.1016/j.apradiso.2018.12.031.

Carter KP, Deblonde GJP, Lohrey TD, Bailey TA, An DD, Shield KM, et al. Developing scandium and yttrium coordination chemistry to advance theranostic radiopharmaceuticals. Commun Chem. 2020;3(1). https://doi.org/10.1038/s42004-020-03 $07-0$.

Chakravarty R, Goel S, Valdovinos HF, Hernandez R, Hong H, Nickles RJ, et al. Matching the decay half-life with the biological half-life: ImmunoPET imaging with (44)Sc-labeled cetuximab fab fragment. Bioconjug Chem. 2014;25(12):2197-204. https://doi.org/10.1021/bc500415x.

Chakravarty R, Chakraborty S, Ram R, Dash A. An electroamalgamation approach to separate 47Sc from neutron-activated 46Ca target for use in cancer theranostics. Sep Sci Technol. 2017;52(14):2363-71. https://doi.org/10.1080/01496395.201 7.1295994.

Chaple IF, Lapi SE. Production and use of the first-row transition metal PET radionuclides (43,44)Sc, (52)Mn, and (45)Ti. J Nucl Med. 2018:59(11):1655-9. https://doi.org/10.2967/jnumed.118.213264.

Coenen HH, Gee AD, Adam M, Antoni G, Cutler CS, Fujibayashi Y, et al. Consensus nomenclature rules for radiopharmaceutical chemistry — setting the record straight. Nucl Med Biol. 2017;55:v-xi.

Deilami-Nezhad L, Moghaddam-Banaem L, Sadeghi M, Asgari M. Production and purification of Scandium-47: a potential radioisotope for cancer theranostics. Appl Radiat Isot. 2016;118:124-30. https://doi.org/10.1016/j.apradiso.2016.09.004.

Deilami-Nezhad L, Moghaddam-Banaem L, Sadeghi M. Development of bone seeker radiopharmaceuticals by Scandium-47 and estimation of human absorbed dose. Appl Radiat Isot. 2017;129:108-16. https://doi.org/10.1016/ j.apradiso.2017.07.062.

Ditroi F, Tarkanyi F, Takacs S, Hermanne A. Activation cross-sections of proton induced reactions on vanadium in the 37-65 MeV energy range. Nucl Instrum Meth B. 2016;381:16-28. https://doi.org/10.1016/..nimb.2016.05.015.

Domnanich KA, Eichler R, Muller C, Jordi S, Yakusheva V, Braccini S, et al. Production and separation of (43)Sc for radiopharmaceutical purposes. EJNMMI Radiopharm Chem. 2017b;2(1):14. https://doi.org/10.1186/s41181-017-0033-9.

Domnanich KA, Muller C, Benesova M, Dressler R, Haller S, Koster U, et al. (47)Sc as useful beta(-)-emitter for the radiotheragnostic paradigm: a comparative study of feasible production routes. EJNMMI Radiopharm Chem. 2017a;2(1):5.

Domnanich KA, Muller C, Farkas R, Schmid RM, Ponsard B, Schibli R, et al. (44)Sc for labeling of DOTA- and NODAGAfunctionalized peptides: preclinical in vitro and in vivo investigations. EJNMMI Radiopharm Chem. 2017c;1(1):8. 
Duchemin C, Guertin A, Haddad F, Michel N, Metivier V. Production of scandium-44 m and scandium-44 g with deuterons on calcium-44: cross section measurements and production yield calculations. Phys Med Biol. 2015;60(17):6847-64. https:// doi.org/10.1088/0031-9155/60/17/6847.

Duchemin C, Guertin A, Haddad F, Michel N, Métivier V. Corrigendum: production of scandium-44m and scandium-44g with deuterons on calcium-44: cross section measurements and production yield calculations. Phys Med Biol. 2016;60:6847-64.

Duval JE, Kurbatov MH. Separation of carrier-free scandium from a calcium target. J Am Chem Soc. 1953;75(9):2246.

EDQM. General monograph: 0125, radiopharmaceutical preparations, European pharmacopeia. 10th ed. Strasbourg: Council of Europe; 2020a.

EDQM. Monograph: 2798, lutetium (177Lu) solution for radiolabelling, European pharmacopeia. 10th ed. Strasbourg: Council of Europe; $2020 \mathrm{~b}$.

EDQM. Monograph: 2803, yttrium (90Y) chloride solution for radiolabelling yttrium (90Y) chloride solution for radiolabelling European pharmacopeia. 10th ed. Strasbourg: Council of Europe; 2020c.

EDQM. Monograph: 2464, gallium (68Ga) chloride solution for radiolabelling, European pharmacopeia. 10th ed. Strasbourg: Council of Europe; $2020 \mathrm{~d}$

EDQM. Monograph: 3109, gallium (68Ga) chloride (accelerator-produced) solution for radiolabelling, European pharmacopeia. 10th ed. Strasbourg: Council of Europe; 2020e.

EDQM. Monograph: 2891, sodium Pertechnetate (99mTc) injection (accelerator-produced), European pharmacopeia. 10th ed. Strasbourg: Council of Europe; $2020 f$.

Eigner S, Vera DR, Fellner M, Loktionova NS, Piel M, Lebeda O, et al. Imaging of protein synthesis: in vitro and in vivo evaluation of (44)Sc-DOTA-puromycin. Mol Imaging Biol. 2013;15(1):79-86. https://doi.org/10.1007/s11307-012-0561-3.

Eppard E, de la Fuente A, Benesova M, Khawar A, Bundschuh RA, Gartner FC, et al. Clinical translation and first in-human use of [(44)Sc]Sc-PSMA-617 for PET imaging of metastasized castrate-resistant prostate cancer. Theranostics. 2017;7(18):435969. https://doi.org/10.7150/thno.20586.

Eppard E, de la Fuente A, Mohr N, Allmeroth M, Zentel R, Miederer M, et al. Labeling of DOTA-conjugated HPMA-based polymers with trivalent metallic radionuclides for molecular imaging. EJNMMI Res. 2018;8(1):16. https://doi.org/10.1186/ s13550-018-0372-x.

Eppard E. Pre-therapeutic dosimetry employing scandium-44 for radiolabeling PSMA-617: Conference proceedings; 2018. https://doi.org/10.5772/intechopen79157.

EU Commission. Directive 2001/83/EC of the European Parliament and of the council of 6 November 2001 on the community code relating to medicinal products for human use. Off J Eur Communities. 2004;311:67-128.

Fani M, Maecke HR. Radiopharmaceutical development of radiolabelled peptides. Eur J Nucl Med Mol Imaging. 2012;39(Suppl 1): S11-30.

Ferguson S, Wuest M, Richter S, Bergman C, Dufour J, Krys D, et al. A comparative PET imaging study of 44gSC- and 68Galabeled bombesin antagonist BBN2 derivatives in breast and prostate cancer models. Nucl Med Biol. 2020;90-91:74-83.

Filosofov DV, Loktionova NS, Rösch F. A 44Ti/44Sc radionuclide generator for potential application of 44Sc-based PETradiopharmaceuticals. Radiochim Acta. 2010;98(3):149-56.

Garcia-Torano E, Peyres V, Roteta M, Sanchez-Cabezudo Al, Romero E, Martinez OA. Standardisation and precise determination of the half-life of (44)Sc. Appl Radiat Isot. 2016;109:314-8. https://doi.org/10.1016/j.apradiso.2015.12.007.

Gelbart WZ, Johnson RR. Solid target system with in-situ target dissolution. Instruments. 2019;3(1):14.

Gizawy MA, Mohamed NMA, Aydia MI, Soliman MA, Shamsel-Din HA. Feasibility study on production of Sc-47 from neutron irradiated Ca target for cancer theranostics applications. Radiochim Acta. 2020;108(3):207-15. https://doi.org/10.1515/ra ct-2018-3070.

Hernandez R, Valdovinos HF, Yang Y, Chakravarty R, Hong H, Barnhart TE, et al. 44Sc: an attractive isotope for peptide-based PET imaging. Mol Pharm. 2014;11(8):2954-61. https://doi.org/10.1021/mp500343j.

Hoehr C, Oehlke E, Benard F, Lee CJ, Hou X, Badesso B, et al. (44g)Sc production using a water target on a $13 \mathrm{MeV}$ cyclotron. Nucl Med Biol. 2014;41(5):401-6. https://doi.org/10.1016/j.nucmedbio.2013.12.016.

Honarvar H, Muller C, Cohrs S, Haller S, Westerlund K, Karlstrom AE, et al. Evaluation of the first (44)Sc-labeled Affibody molecule for imaging of HER2-expressing tumors. Nucl Med Biol. 2017;45:15-21. https://doi.org/10.1016/j.nucmedbio.2016.10.004.

Howard AJ, Jensen HB, Rios M, Fowler WA, Zimmerman BA. Measurement and theoretical analysis of some reaction rates of interest in silicon burning. Astroph J. 1974;188:131.

Huclier-Markai S, Sabatie A, Ribet S, Kubícek V, Paris M, Vidaud C, et al. Chemical and biological evaluation of scandium(III)polyaminopolycarboxylate complexes as potential PET agents and radiopharmaceuticals. Radiochim Acta. 2011;99(10): 653-62. https://doi.org/10.1524/ract.2011.1869.

Huclier-Markai S, Alliot C, Sebti J, Brunel B, Aupiais J. A comparative thermodynamic study of the formation of scandium complexes with DTPA and DOTA. RSC Adv. 2015;5(121):99606-17. https://doi.org/10.1039/C5RA16736A.

Huclier-Markai S, Alliot C, Kerdjoudj R, Mougin-Degraef M, Chouin N, Haddad F. Promising scandium radionuclides for nuclear medicine: a review on the production and chemistry up to in vivo proofs of concept. Cancer Biother Radiopharm. 2018; 33(8):316-29. https://doi.org/10.1089/cbr.2018.2485.

Jafari A, Aboudzadeh MR, Azizakram H, Sadeghi M, Alirezapour B, Rajabifar S, et al. Investigations of proton and deuteron induced nuclear reactions on natural and enriched titanium, calcium and vanadium targets, with special reference to the production of (47)Sc. Appl Radiat Isot. 2019;152:145-55. https://doi.org/10.1016/j.apradiso.2019.07.007.

Jalilian AR, Gizawy MA, Alliot C, Takacs S, Chakarborty S, Rovais MRA, et al. IAEA activities on 67Cu, 186Re, 47SC Theranostic radionuclides and radiopharmaceuticals. Curr Radiopharm. 2020;13:1.

Kalyanaraman S, Khopkar SM. Solvent extraction separation of scandium with 4-methyl-3-penten-2-one as its thiocyanate complex. Anal Chem. 2002:49(8):1192-4.

Kan AT, Fu G, Tomson MB. Effect of methanol on carbonate equilibrium and calcite solubility in a gas/methanol/water/salt mixed system. Langmuir. 2002;18(25):9713-25. https://doi.org/10.1021/la025620n.

Kerdjoudj R, Pniok M, Alliot C, Kubicek V, Havlickova J, Rosch F, et al. Scandium(III) complexes of monophosphorus acid DOTA analogues: a thermodynamic and radiolabelling study with (44)Sc from cyclotron and from a (44)Ti/(44)Sc generator. Dalton Trans. 2016;45(4):1398-409. https://doi.org/10.1039/C5DT04084A. 
Khawar A, Eppard E, Sinnes JP, Roesch F, Ahmadzadehfar H, Kurpig S, et al. [44Sc]Sc-PSMA-617 biodistribution and Dosimetry in patients with metastatic castration-resistant prostate carcinoma. Clin Nucl Med. 2018a;43(5):323-30. https://doi.org/10.1 097/RLU.0000000000002003.

Khawar A, Eppard E, Sinnes JP, Roesch F, Ahmadzadehfar H, Kurpig S, et al. Prediction of Normal organ absorbed doses for [177Lu]Lu-PSMA-617 using [44Sc]Sc-PSMA-617 pharmacokinetics in patients with metastatic castration resistant prostate carcinoma. Clin Nucl Med. 2018b;43(7):486-91. https://doi.org/10.1097/RLU.0000000000002102.

Kilbourn MR, Scott PJH. Issues in preclinical radiopharmaceutical research: significance, relevance and reproducibility. Nucl Med Biol. 2018;67:52-5. https://doi.org/10.1016/j.nucmedbio.2018.07.002.

Kilian K, Cheda L, Sitarz M, Szkliniarz K, Choinski J, Stolarz A. Separation of (44)Sc from natural calcium carbonate targets for synthesis of (44)Sc-DOTATATE. Molecules. 2018;23(7):1787.

Kolsky KL, Joshi V, Mausner LF, Srivastava SC. Radiochemical purification of no-carrier-added scandium-47 for radioimmunotherapy. Appl Radiat Isot. 1998;49(12):1541-9. https://doi.org/10.1016/S0969-8043(98)00016-5.

Kostelnik TI, Orvig C. Radioactive Main group and rare earth metals for imaging and therapy. Chem Rev. 2019;119(2):902-56 https://doi.org/10.1021/acs.chemrev.8b00294.

Koumarianou E, Pawlak D, Korsak A, Mikolajczak R. Comparison of receptor affinity of natSc-DOTA-TATE versus natGa-DOTATATE. Nucl Med Rev Cent East Eur. 2011;14(2):85-9. https://doi.org/10.5603/NMR.2011.00021.

Koning AJ, Rochman D, Kopecky J, Sublet J.Ch, Bauge E, Hilaire S, Romain P, Morillon B, Duarte H, van der Marck S, Pomp S, Siostrand H, Forrest R, Henriksson H, Cabellos O, Goriely S, Leppanen J, Leeb H, Plompen S, Mills R. TALYS-based evaluated nuclear data library TENDL 2015. (2016).

Koumarianou E, Loktionova NS, Fellner M, Roesch F, Thews O, Pawlak D, et al. 44Sc-DOTA-BN[2-14]NH2 in comparison to 68Ga-DOTA-BN[2-14]NH2 in pre-clinical investigation. Is 44SC a potential radionuclide for PET? Appl Radiat Isot. 2012; 70(12):2669-76. https://doi.org/10.1016/j.apradiso.2012.08.004.

Krajewski S, Cydzik I, Abbas K, Bulgheroni A, Simonelli F, Holzwarth U, et al. Cyclotron production of 44Sc for clinical application. Radiochim Acta. 2013;101(5):333-8. https://doi.org/10.1524/ract.2013.2032.

Krajewski S, Cydzik I, Abbas K, Simonelli F, Bulgheroni A, Kasperek A, Majkowska-Pilip A, Holzwarth U, Bilewicz A. Theranostic pair for peptide receptor radionuclide therapy $-43,44 S c$ and 47Sc, EuCheMS International Conference on Nuclear and Radiochemistry (NRC-8), Como (Italy) 2012 Sep 16-21 book of Abstract p.7.

Li L, Jaraquemada-Pelaez MG, Kuo HT, Merkens H, Choudhary N, Gitschtaler K, et al. Functionally versatile and highly stable Chelator for (111)in and (177)Lu: proof-of-principle prostate-specific membrane antigen targeting. Bioconjug Chem. 2019a;30(5):1539-53. https://doi.org/10.1021/acs.bioconjchem.9b00225.

Li L, Kostelnik T, Radchenko V, Mynerich J, Bénard F, Wilbur S, et al. New bifunctional chelators for diagnostic and therapeutic radioisotopes. Nucl Med Biol. 2019b;72-73:S36-S7.

Lima TV, Gnesin S, Nitzsche E, Ortega PG, Müller C, van der Meulen NP. First phantom-based quantitative assessment of scandium-44 using a commercial PET device. Front Phys. 2020;8:241. https://doi.org/10.3389/fphy.2020.00241.

Lommel B, Beusch A, Hartmann W, Hübner A, Kindler B, Steiner J, et al. Reduction of isotopically enriched 50Ti-dioxide for the production of high-intensity heavy-ion beam. J Radioanal Nucl Chem. 2013;299(2):977-80.

Loveless CS, Blanco JR, Braccini S, Lapi S. Evaluation of cyclotron produced ${ }^{43,44,47}$ SC from titanium (0) and titanium dioxide. J Label Compd Radiopharm. 2019b;1:569-70.

Loveless CS, Radford LL, Ferran SJ, Queern SL, Shepherd MR, Lapi SE. Photonuclear production, chemistry, and in vitro evaluation of the theranostic radionuclide (47)Sc. EJNMMI Res. 2019a;9(1):42. https://doi.org/10.1186/s13550-019-0515-8.

Loveless CS, Blanco JR, Diehl GL 3rd, Elbahrawi RT, Carzaniga TS, Braccini S, et al. Cyclotron production and separation of scandium radionuclides from natural titanium metal and titanium dioxide targets. J Nucl Med. 2021;62(1):131-6. https:// doi.org/10.2967/jnumed.120.242941.

Majkowska-Pilip A, Bilewicz A. Macrocyclic complexes of scandium radionuclides as precursors for diagnostic and therapeutic radiopharmaceuticals. J Inorg Biochem. 2011;105(2):313-20. https://doi.org/10.1016/j.jinorgbio.2010.11.003.

Mamtimin M, Harmon F, Starovoitova VN. Sc-47 production from titanium targets using electron linacs. Appl Radiat Isot. 2015;102:1-4. https://doi.org/10.1016/j.apradiso.2015.04.012.

Mausner L. Radionuclide development at BNL for nuclear medicine therapy. Appl Radiat Isot. 1998;49:285-94.

Mausner LFKK, Mease RC, et al. Production and evaluation of Sc-47 for radioimmunotherapy. J Label Compd Radiopharm. 1993;32:388-90.

Mausner LF, Srivastava SC. Selection of radionuclides for radioimmunotherapy. Med Phys. 1993;20(2 Pt 2):503-9. https://doi. org/10.1118/1.597045.

Mausner LFJV, Kolsky KL, Menken GE, Mease RC, Sweet MP, Srivastave SC. Evaluation of chelating agents for radioimmunotherpay with scandium-47. J Nucl Med. 1995;36:104.

Mikolajczak R, Pawlak D, Wojdowska W, Janiak T, Barcikowski T, Zoltowska M, et al. Cyclotron production of Sc-44 from natural calcium. J Nucl Med. 2018;59:1043.

Mikolajczak R, van der Meulen NP, Lapi SE. Radiometals for imaging and theranostics, current production and future perspectives. J Labelled Comp Radiopharm. 2019;62(10):615-34. https://doi.org/10.1002/jlcr.3770.

Minegishi K, Nagatsu K, Fukada M, Suzuki H, Ohya T, Zhang MR. Production of scandium-43 and -47 from a powdery calcium oxide target via the (nat/44)Ca(alpha,x)-channel. Appl Radiat Isot. 2016;116:8-12. https://doi.org/10.1016/j.apradiso.2016.07.017.

Misiak R, Walczak R, Was B, Bartyzel M, Mietelski JW, Bilewicz A. (47)Sc production development by cyclotron irradiation of (48)Ca. J Radioanal Nucl Chem. 2017;313(2):429-34. https://doi.org/10.1007/s10967-017-5321-z.

Moghaddam-Banaem L. Development of a radioscandium immunoconjugate for radioimmunotherapy. Radiochim Acta. 2012;100:215-21.

Muller C, Bunka M, Haller S, Koster U, Groehn V, Bernhardt P, et al. Promising prospects for 44Sc-/47Sc-based theragnostics: application of 47Sc for radionuclide tumor therapy in mice. J Nucl Med. 2014;55(10):1658-64. https://doi.org/10.2967/ jnumed.114.141614.

Muller C, Domnanich KA, Umbricht CA, van der Meulen NP. Scandium and terbium radionuclides for radiotheranostics: current state of development towards clinical application. Br J Radiol. 2018;91(1091):20180074. https://doi.org/10.1259/ bjr.20180074. 
Nagy G, Denes N, Kis A, Szabo JP, Berenyi E, Garai I, et al. Preclinical evaluation of melanocortin-1 receptor (MC1-R) specific (68)Ga- and (44)Sc-labeled DOTA-NAPamide in melanoma imaging. Eur J Pharm Sci. 2017b;106:336-44. https://doi.org/1 0.1016/j.ejps.2017.06.026.

Nagy G, Szikra D, Trencsenyi G, Fekete A, Garai I, Giani AM, et al. AAZTA: an ideal chelating agent for the development of (44) SC PET imaging agents. Angew Chem Int Ed Eng. 2017a;56(8):2118-22. https://doi.org/10.1002/anie.201611207.

Neels O, Patt M, Decristoforo C. Radionuclides: medicinal products or rather starting materials? EJNMMI Radiopharm Chem. 2019;4(1):22. https://doi.org/10.1186/s41181-019-0074-3.

Pawlak D, Wojdowska W, Parus LJ, Cieszykowska I, Zoltowska M, Garnuszek P, et al. Comparison of separation methods for 47Ca/47Sc radionuclide generator. Appl Radiat Isot. 2019;151:140-4. https://doi.org/10.1016/j.apradiso.2019.05.020.

Pietrelli L, Mausner LF, Kolsky KL. Separation of carrier-free47Sc from titanium targets. J Radioanal Nucl Chem Artic. 1992; 157(2):335-45. https://doi.org/10.1007/BF02047448

Pniok M, Kubicek V, Havlickova J, Kotek J, Sabatie-Gogova A, Plutnar J, et al. Thermodynamic and kinetic study of scandium(III) complexes of DTPA and DOTA: a step toward scandium radiopharmaceuticals. Chemistry. 2014;20(26):794455. https://doi.org/10.1002/chem.201402041.

Polosak M, Piotrowska A, Krajewski S, Bilewicz A. Stability of (47)Sc-complexes with acyclic polyamino-polycarboxylate ligands. J Radioanal Nucl Chem. 2013;295(3):1867-72. https://doi.org/10.1007/s10967-012-2188-x.

Pourmand A, Dauphas N. Distribution coefficients of 60 elements on TODGA resin: application to Ca, Lu, Hf, U and Th isotope geochemistry. Talanta. 2010;81(3):741-53. https://doi.org/10.1016/j.talanta.2010.01.008.

Pruszynski M, Loktionova NS, Filosofov DV, Rosch F. Post-elution processing of (44)Ti/(44)Sc generator-derived (44)Sc for clinical application. Appl Radiat Isot. 2010;68(9):1636-41. https://doi.org/10.1016/j.apradiso.2010.04.003.

Pruszynski M, Majkowska-Pilip A, Loktionova NS, Eppard E, Roesch F. Radiolabeling of DOTATOC with the long-lived positron emitter 44Sc. Appl Radiat Isot. 2012;70(6):974-9. https://doi.org/10.1016/j.apradiso.2012.03.005.

Pupillo G, Mou L, Boschi A, Calzaferri S, Canton L, Cisternino S, et al. Production of 47SC with natural vanadium targets: results of the PASTA project. J Radioanal Nucl Chem. 2019;322(3):1711-8. https://doi.org/10.1007/s10967-019-06844-8.

Qaim SM. Theranostic radionuclides: recent advances in production methodologies. J Radioanal Nucl Chem. 2019;322(3): 1257-66. https://doi.org/10.1007/s10967-019-06797-y.

Radchenko V, Meyer CAL, Engle JW, Naranjo CM, Unc GA, Mastren T, et al. Separation of (44)Ti from proton irradiated scandium by using solid-phase extraction chromatography and design of (44)Ti/(44)Sc generator system. J Chromatogr A. 2016;1477:39-46. https://doi.org/10.1016/j.chroma.2016.11.047.

Radhakrishnan KP, Owens TC. Separation of scandium and calcium by liquid-liquid extraction using tributyl phosphate as solvent. J Chem Eng Data. 1972;17(4):478-82. https://doi.org/10.1021/je60055a038.

Rane AT, Bhatki KS. Rapid radiochemical separations of Strontium-90-Yttrium-90 and Calcium-45-Scandium-46 on a Cation exchange resin. Anal Chem. 1966;38(11):1598-601. https://doi.org/10.1021/ac60243a039.

Rane S, Harris JT, Starovoitova VN. (47)Ca production for (47)Ca/(47)Sc generator system using electron linacs. Appl Radiat Isot. 2015;97:188-92. https://doi.org/10.1016/j.apradiso.2014.12.020.

Roesch F. Scandium-44: benefits of a long-lived PET radionuclide available from the 44Ti/44Sc generator system. Curr Radiopharm. 2012:5(3):187-201. https://doi.org/10.2174/1874471011205030187.

Rosar F, Buchholz HG, Michels S, Hoffmann MA, Piel M, Waldmann CM, et al. Image quality analysis of (44)SC on two preclinical PET scanners: a comparison to (68)Ga. EJNMMI Phys. 2020;7(1):16. https://doi.org/10.1186/s40658-020-0286-3.

Rotsch DA, Brown MA, Nolen JA, Brossard T, Henning WF, Chemerisov SD, et al. Electron linear accelerator production and purification of scandium-47 from titanium dioxide targets. Appl Radiat Isot. 2018;131:77-82. https://doi.org/10.1016/j.apra diso.2017.11.007.

Severin GW, Engle JW, Valdovinos HF, Barnhart TE, Nickles RJ. Cyclotron produced (4)(4)gSc from natural calcium. Appl Radiat Isot. 2012;70(8):1526-30. https://doi.org/10.1016/j.apradiso.2012.04.030.

Singh B, Chen J. Nuclear data sheets for $a=43$. Nuclear Data Sheets. 2015;126:1-150. https://doi.org/10.1016/j.nds.2015.05.001.

Singh A, van der Meulen NP, Muller C, Klette I, Kulkarni HR, Turler A, et al. First-in-human PET/CT imaging of metastatic neuroendocrine neoplasms with cyclotron-produced (44)Sc-DOTATOC: a proof-of-concept study. Cancer Biother Radiopharm. 2017;32(4):124-32. https://doi.org/10.1089/cbr.2016.2173.

Sinnes JP, Nagel J, Rosch F. AAZTA(5)/AAZTA(5)-TOC: synthesis and radiochemical evaluation with (68)Ga, (44)SC and (177)Lu. EJNMMI Radiopharm Chem. 2019;4(1):18. https://doi.org/10.1186/s41181-019-0068-1.

Sitarz M. Radionuclide candidates for $\beta+\gamma$ coincidence PET: an overview; 2020.

Sitarz M, Szkliniarz K, Jastrzebski J, Choinski J, Guertin A, Haddad F, et al. Production of Sc medical radioisotopes with proton and deuteron beams. Appl Radiat Isot. 2018;142:104-12. https://doi.org/10.1016/j.apradiso.2018.09.025.

Siwowska K, Guzik P, Domnanich KA, Monne Rodriguez JM, Bernhardt P, Ponsard B, et al. Therapeutic potential of (47)SC in comparison to (177)Lu and (90)Y: preclinical investigations. Pharmaceutics. 2019;11(8):424.

Srivastava SC. A bridge not too far: personalized medicine with the use of Theragnostic radiopharmaceuticals. J Postgrad Med Educ Res. 2013;47(1):31-46. https://doi.org/10.5005/jp-journals-10028-1054.

Srivastava S, Dadachova E. Recent advances in radionuclide therapy. Semin Nucl Med. 2001;31(4):330-41. https://doi.org/10.1 053/snuc.2001.27043.

Starovoitova VN, Cole PL, Grimm TL. Accelerator-based photoproduction of promising beta-emitters 67Cu and 47Sc. J Radioanal Nucl Chem. 2015;305(1):127-32. https://doi.org/10.1007/s10967-015-4039-z.

Stolarz AKJ, Jastrzębski J, Choiński J, et al. Targets for production of the medical radioisotopes with alpha and proton or deuteron beams. AIP Confer Proc. 2018;1962:020004.

Synowiecki MA, Perk LR, Nijsen JFW. Production of novel diagnostic radionuclides in small medical cyclotrons. EJNMMI Radiopharm Chem. 2018;3(1):3. https://doi.org/10.1186/s41181-018-0038-z.

Szkliniarz K, Sitarz M, Walczak R, Jastrzebski J, Bilewicz A, Choinski J, et al. Production of medical Sc radioisotopes with an alpha particle beam. Appl Radiat Isot. 2016;118:182-9. https://doi.org/10.1016/j.apradiso.2016.07.001.

Umbricht CA, Benesova M, Schmid RM, Turler A, Schibli R, van der Meulen NP, et al. (44)Sc-PSMA-617 for radiotheragnostics in tandem with (177)Lu-PSMA-617-preclinical investigations in comparison with (68)Ga-PSMA-11 and (68)Ga-PSMA-617. EJNMMI Res. 2017;7(1):9. 
Valdovinos HF, Hernandez R, Barnhart TE, Graves S, Cai W, Nickles RJ. Separation of cyclotron-produced (44)Sc from a natural calcium target using a dipentyl pentylphosphonate functionalized extraction resin. Appl Radiat Isot. 2015;95:23-9. https:// doi.org/10.1016/j.apradiso.2014.09.020.

van der Meulen NP, Bunka M, Domnanich KA, Muller C, Haller S, Vermeulen C, et al. Cyclotron production of (44)Sc: from bench to bedside. Nucl Med Biol. 2015;42(9):745-51. https://doi.org/10.1016/j.nucmedbio.2015.05.005.

van der Meulen NP, Hasler R, Talip Z, Grundler PV, Favaretto C, Umbricht CA, et al. Developments toward the implementation of (44)Sc production at a medical cyclotron. Molecules. 2020;25(20):4706.

Vaughn BA, Ahn SH, Aluicio-Sarduy E, Devaraj J, Olson AP, Engle J, et al. Chelation with a twist: a bifunctional chelator to enable room temperature radiolabeling and targeted PET imaging with scandium-44. Chem Sci. 2020a;11(2):333-42. https://doi.org/10.1039/C9SC04655K.

Vaughn BA, Ahn SH, Aluicio-Sarduy E, Devaraj J, Olson AP, Engle J, et al. Chelation with a twist: a bifunctional chelator to enable room temperature radiolabeling and targeted PET imaging with scandium-44. Chem Sci. 2020b;11(2):333-42. https://doi.org/10.1039/C9SC04655K.

Velikyan IGA, Sörensen J, Estrada S. Organ biodistribution of Germanium-68 in rat in the presence and absence of [68Ga]GaDOTA-TOC for the extrapolation to the human organ and whole-body radiation dosimetry. Am J Nucl Med Mol Imaging. 2013;3:154

Vibhute C, Khopkar S. Separation of scandium(III) as citrate complex by extraction with aliquat 336S. Indian J Chem. 1985;24A: 444-6.

Walczak R, Krajewski S, Szkliniarz K, Sitarz M, Abbas K, Choinski J, et al. Cyclotron production of (43)Sc for PET imaging. EJNMMI Phys. 2015;2(1):33. https://doi.org/10.1186/s40658-015-0136-x.

Walczak R, Gawęda W, Dudek J, Choiński J, Bilewicz A. Influence of metal ions on the 44Sc-labeling of DOTATATE. J Radioanal Nucl Chem. 2019;322(2):249-54. https://doi.org/10.1007/s10967-019-06700-9.

Wojdowska W. Improved procedures of Sc(OH)3 precipitation and UTEVA extraction for 44Sc separation. Nucl Med Rev. 2019; 22:56-9.

Yagi M, Kondo K. Preparation of carrier-free 47Sc by the 48Ti (y,p) reaction. Int J Appl Radiat Isotopes. 1977;28(5):463-8. https://doi.org/10.1016/0020-708X(77)90178-8.

Zhang P, You S, Zhang L, Feng S, Hou S. A solvent extraction process for the preparation of ultrahigh purity scandium oxide. Hydrometallurgy. 1997;47(1):47-56. https://doi.org/10.1016/S0304-386X(97)00033-9.

\section{Publisher's Note}

Springer Nature remains neutral with regard to jurisdictional claims in published maps and institutional affiliations.

\section{Submit your manuscript to a SpringerOpen ${ }^{\circ}$ journal and benefit from:}

- Convenient online submission

- Rigorous peer review

- Open access: articles freely available online

- High visibility within the field

- Retaining the copyright to your article

Submit your next manuscript at $\boldsymbol{\nabla}$ springeropen.com 